\title{
Effectiveness of CFD simulation for the performance prediction of phase change building boards in the thermal environment control of indoor spaces
}

\author{
B.L. Gowreesunker ${ }^{a}$, S.A. Tassou ${ }^{b}$ \\ Howell Building, Mechanical Engineering, School of Engineering and Design, Brunel \\ University, Uxbridge, Middlesex, UB8 3PH, UK \\ ${ }^{a}$ Corresponding Author: lesh g@yahoo.com (B.L. Gowreesunker) \\ ${ }^{b}$ Savvas.Tassou@brunel.ac.uk (S.A Tassou) \\ ${ }^{a}$ Tel: +44(0) 1895277220 (United Kingdom) \\ ${ }^{b}$ Tel: +44 (0)1895 266865 (United Kingdom)
}

\section{Abstract}

This paper reports on a validation study of CFD models used to predict the effect of PCM clay boards on the control of indoor environments, in ventilated and non-ventilated situations. Unlike multi-zonal models, CFD is important in situations where localised properties are essential such as in buildings with complex and large geometries. The employed phase change model considers temperature/enthalpy hysteresis and varying enthalpy-temperature characteristics to more accurately simulate the phase change behaviour of the PCM boards compared to the standard default modelling approach in the commercial CFD codes. Successful validation was obtained with a mean error of $1.0 \mathrm{~K}$ relative to experimental data, and the results show that in addition to providing satisfactory quantitative results, CFD also provides qualitative results which are useful in the effective design of indoor thermal environment control systems utilising PCM. These results include: i) temperature and air flow distribution within the space resulting from the use of PCM boards and different night ventilation rates; ii) the fraction of PCM experiencing phase change and is effective in the control of the indoor thermal environment, enabling optimisation of the location of the boards; and iii) the energy impact of PCM boards and adequate ventilation configurations for effective night charging. 
Keywords: Computational fluid dynamics (CFD), FLUENT, Phase change materials (PCM), PCM-clay boards, Building design, Temperature/enthalpy hysteresis.

\section{Nomenclature}

\begin{tabular}{|c|c|}
\hline$\rho$ & Density $\left(\mathrm{kg} / \mathrm{m}^{3}\right)$ \\
\hline$T$ & Temperature (K) \\
\hline$h$ & Enthalpy $(\mathrm{J} / \mathrm{kg})$ \\
\hline$t$ & Time $(s)$ \\
\hline$x_{j}$ & Direction vector \\
\hline$u_{i, j}$ & Velocity vectors \\
\hline$c_{p}$ & Specific heat capacity (J/kg K) \\
\hline$\lambda$ & Thermal conductivity $(\mathrm{W} / \mathrm{mK})$ \\
\hline$S_{M}$ & Mass source term $\left(\mathrm{kg} / \mathrm{m}^{3}\right)$ \\
\hline$S_{E}$ & Energy source term $\left(\mathrm{W} / \mathrm{m}^{3}\right)$ \\
\hline$P$ & Static Pressure $(\mathrm{Pa})$ \\
\hline $\bar{\tau}$ & Stress tensor \\
\hline$g_{j}$ & Gravitational force vector \\
\hline$F_{j}$ & Body force vector \\
\hline$\beta$ & Thermal expansion coefficient $\left(\mathrm{K}^{-1}\right)$ \\
\hline$S_{E f, m}$ & Freezing/ Melting energy source term \\
\hline$\Delta h$ & Uncertainty in enthalpy $(\mathrm{J} / \mathrm{kg})$ \\
\hline$V_{i}$ & Cell Volume \\
\hline$\Phi_{i}$ & Cell Parameter \\
\hline $\bar{q}$ & Area-weighted walls' heat flux $\left(\mathrm{W} / \mathrm{m}^{2}\right)$ \\
\hline$T_{\text {inlet }}$ & Air inlet/ Reference temperature (K) \\
\hline$\overline{\overline{T_{\text {surf }}}}$ & Area-weighted walls' surface temperature (K) \\
\hline$N_{t}$ & Number of time-steps \\
\hline
\end{tabular}




\subsection{Introduction}

Phase change materials (PCM), in the context of buildings, refer to materials with enhanced heat storage capabilities in a specific temperature range through the utilisation of the latent heat of phase change. The growing trend in the design of thermally less massive buildings, with maximum exposure to the outdoor environment, decreases the thermal inertia of the building envelope, leading to higher indoor temperature swings and energy consumption [1]. As a result, PCM in its various forms have been introduced to compensate for the lack of thermal mass in the building envelope. PCM are energy storage materials and must therefore be replenished/ recharged after being used. In the case of PCM boards, night ventilation is a very common method used to recharge PCM during the summer, whereby cool night air is passed through the building and absorbs the heat stored during daytime [1, $2,3,4,5]$.

PCMs have been extensively studied in the literature for various building thermal control applications, with encouraging results $[2,5,6]$. However, because of the complexity in building operation, construction, architecture, and weather conditions, the results of previous studies are limited to specific cases [7]: such as offices [8]; or specific climatic regions [9]. Various commercial simulation tools such as ESP-r [10] and TRNSYS [11], amongst others, incorporate phase change modelling capabilities. However, they do not allow for detailed evaluation of the air flow and temperature in the space, which is becoming increasingly important as the indoor design of buildings becomes more complex. Furthermore, the percentage of PCM being effectively active and used, cannot be determined through the zonal models. 
In indoor spaces, air flows are generally initiated by: buoyancy forces arising from local heat gains from occupants, equipment and heating systems; forced convection from heating, ventilation and air conditioning systems (HVAC); or mixed buoyancy/forced sources. Previous studies have investigated these phenomena under different scenarios, and as a result, various validations of the use of CFD to predict indoor thermal and flow conditions are found in the literatures $[12,13,14]$. The emphasis of most studies to date, however, has mainly been on indoor air quality investigations to predict contaminant concentrations, natural ventilation designs, and investigations of stratified environments [12]. This study aims at extending the realm of CFD to PCM performance evaluation, as proposed by the IEA [7].

\subsection{Computational Fluid Dynamics (CFD)}

Computational Fluid Dynamics (CFD) can be used to predict air flow and temperature fields in indoor environments by numerically solving the Navier-Stokes set of partial differential equations for mass, energy and momentum. These equations are linearised, discretised, and applied to finite volumes in the solver to obtain a detailed solution, including velocity and temperature fields.

Mass Equation:

$$
\frac{\partial \rho}{\partial t}+\frac{\partial}{\partial x_{j}}\left(\rho u_{j}\right)=S_{M}
$$

Energy Equation:

$$
\frac{\partial}{\partial t}(\rho H)=-\frac{\partial}{\partial x_{j}}\left(\rho u_{j} c_{p} T\right)+\frac{\partial}{\partial x_{j}}\left[\lambda \frac{\partial T}{\partial x_{j}}\right]+S_{E}
$$

Momentum Equation:

$$
\frac{\partial}{\partial t}\left(\rho u_{j}\right)+\frac{\partial}{\partial x_{j}}\left(\rho u_{i} u_{j}\right)=-\frac{\partial}{\partial x_{j}}(P)+\frac{\partial}{\partial x_{j}}(\bar{\tau})+\rho g_{j}+F_{j} \quad \text { - Eq. } 3
$$


The complexity in simulating air flows in buildings lies mainly in the choice of a turbulence model that can accurately predict the different types of flows encountered in the space. The evaluation of various turbulence models has been the focus of various researchers in the past [15]. The most common models employed are the Reynolds Averaged Navier-Stokes equation (RANS) and the Large Eddy Simulation (LES) for airflows in buildings. The RANS models solve a set of transport conservation equations, while LES requires the separation of small-eddies from large-eddies with a filter [12]. Zhang et al [16] investigated eight turbulence models, including LES for four indoor geometries, under forced, natural and mixed forced/natural ventilation and compared the numerical results with experimental data. They concluded that LES offers the most accurate and detailed results, but required much higher computing time compared to the RANS models. The RNG k- $\varepsilon$ and the modified $V^{2}-f$ models also provided accurate performance over the cases studied. Gebremedhin and Wu [17] simulated a ventilated cattle facility using five RANS models, and concluded that the RNG $k-\varepsilon$ model provided the most suitable flow field modelling. Rohidin et al [18] employed the standard $k-\varepsilon$, the RNG $k-\varepsilon$, and the realizable $k-\varepsilon$ models to simulate a large packaging facility, with a forced ventilation system and considered the effects of buoyancy. They concluded that the RNG $k-\varepsilon$ results are more reliable, in relation to experimental results. Hussain et al [15] investigated six RANS models, including the one-equation model (Spallart-Allamaras), together with the Discrete Transfer Radiation Model (DTRM) in the natural and forced ventilation simulation of atria. In comparison with experimental results, they concluded that the two equation models (the standard $k-\varepsilon$, RNG $k-\varepsilon$, realizable $k-\varepsilon$, standard $k-\omega$ and SST $k-\omega$ models) provided better results compared to the one-equation model, and that SST k- $\omega$ model showed relatively better prediction than the other models. Zhai et al [19] studied turbulence models for 
enclosed indoor environment. They identified that each turbulence models have their advantages and limitations under different situations, and that no universal turbulence model exist for indoor airflow simulations. Tanasic et al [20] investigated the airflow in a mechanically ventilated large industrial hall, including buoyancy, using the standard $k-\varepsilon$ model for turbulence. They concluded that the model did not provide adequate quantitative results as the simulation values differed significantly from the measured values. Suarez et al [21] investigated the forced/buoyant airflow in a glazed gallery using the RNG k- $\varepsilon$, Standard $k-\varepsilon$ and the k- $\omega$ models. They concluded that there were no major differences between the models, and on the basis of stability and simulation time, the RNG k- $\varepsilon$ model was employed in their simulations. However, RNG k- $\varepsilon$ requires slightly higher computational time than the other RANS models $[16,18]$.

On the other hand, LES models tend to offer the most detailed investigation fields but due to the small mesh size and high computer performance requirements, LES has been less popular than the corresponding RANS models. Thus, although there is no ideal turbulence model for a particular type of flow, there is a general consensus from the literature that the RNG $k-\varepsilon$ model produces adequate flow fields for simulations involving buoyant, forced or forced/buoyant flows, similar to the simulations encountered in this study.

In addition to turbulence models, the presence of heat sources in buildings (internal gains) requires an appropriate quantification of buoyancy in the simulation. Previous studies have used the Boussinesq approximations [20], which only include variations in density for the buoyancy term in the momentum equation Eq. 3. This approach has limitations when the temperature gradient in the simulation becomes large (i.e. $\left.\beta\left(T-T_{0}\right)>>1\right)$ [22], such as 
near heat flux heaters. Consequently the ideal-gas approach has also been used to model changes in air density, in which case, the density changes are applied to all conservation equations. However, from the recommendation of ANSYS FLUENT [22], the ideal gas approach for air requires the use of special pressure discretisation schemes in order to provide stable solution. As a result, the Pressure Staggering option (PRESTO) or the bodyforce weighted schemes are often employed for buoyancy driven flows [22].

\subsection{Phase Change Model}

Two main thermal characteristics of phase change are the enthalpy-temperature relationship and temperature hysteresis. Commercial PCMs tend to have varying enthalpytemperature relationships due to the fact that they are blends of different materials, while pure PCMs have a more localised relationship, which can be approximated by single values for the enthalpy and phase change temperature. Hysteresis is the phenomenon whereby the PCM melts and freezes in different temperature ranges and with different enthalpies, i.e. a different temperature-enthalpy curve for melting and freezing. Hysteresis is related to the chemical and kinetic properties of the material [23].

The commonly used enthalpy-porosity model in commercial CFD codes assumes, in its default state, a linear enthalpy-temperature relationship and ignores hysteresis. Susman et al. [5] and Ye et al. [24] employed the enthalpy-porosity method to simulate PCM sails and a PCM plate-fin unit respectively and found the method to produce reasonable temperature prediction in global space temperature terms. The method however produces inaccuracies in transient simulations where time dependent PCM and local wall and air temperatures are of interest. To improve on transient simulation accuracy, Gowreesunker et al. [25] proposed a new method of simulating conduction dominant phase change 
through the use of source terms that considers hysteresis and varying enthalpy-temperature relationship. They showed that in the case of cyclic simulations of PCM boards, the method improves the simulation accuracy over the enthalpy-porosity model by $10 \%$.

Non-linear enthalpy-temperature relationship and hysteresis become important during cyclic simulations. The phase change model employed in this study is thus the semiempirical method, thoroughly described in [25], which requires the enthalpy-temperature curve to be determined via thermal analysis techniques such as Differential Scanning Calorimetry (DSC). As PCM boards are solid materials and conduction heat transfer is dominant inside the material, the governing energy equation can be simplified to Eq. 4, in which the freezing and melting curves are implemented as user defined functions (UDF) (Eq. (6-7)) in the source term $S_{E}$.

$$
\frac{\mathrm{d}}{\mathrm{dt}} \rho H=\frac{\mathrm{d}}{\mathrm{d} x_{j}}\left\lceil\lambda \frac{\mathrm{d} T}{\mathrm{~d} x_{j}}\right\rceil+S_{E} \quad \text { - Eq. } 4
$$

The hysteresis effect is obtained by the separate implementation of the enthalpy curves, and the liquid fraction term, based on the curvature of the enthalpy-porosity relationship, is included through a separate set of equations, but do not contribute to the energy analysis [25].

This study therefore aims to validate the use of CFD to model PCM boards, attached to the internal surfaces of indoor spaces, and their impact on the corresponding air domain. The aim is to facilitate the use of CFD to accurately predict air flow and temperature distribution and resulting comfort and energy consumption in the thermal control of indoor spaces using PCMs. The results can facilitate the optimum integration and utilisation of PCMs in the building fabric. 


\subsection{Experimental Setup}

\subsection{Description of Test Cell}

A test-cell, shown in Fig. 1, with internal dimensions of $1.3 \mathrm{~m} \times 0.8 \mathrm{~m} \times 1.4 \mathrm{~m}$, with a glazed facade of dimension $1.3 \mathrm{~m} \times 0.8 \mathrm{~m}$, was constructed in order to provide a controlled environment to investigate the transient behaviour of air and PCM. The wall/ceiling/floor structure is made of $48 \mathrm{~mm}$ plywood, $90 \mathrm{~mm}$ insulation, $18 \mathrm{~mm}$ plywood, with skimmed PCMClay boards placed on the inside surface of the walls only (Fig. 1). If gypsum plasterboard is used instead of PCM board, the overall U-value of the wall is $0.21 \mathrm{~W} / \mathrm{m}^{2} \mathrm{~K}$, the decrement factor is 0.81 and the time lag is $4.8 \mathrm{hrs}$. These dynamic properties are close to the Timber frame wall as defined by CIBSE [26]. The large double glazed façade has a U-value of 1.2 $\mathrm{W} / \mathrm{m}^{2} \mathrm{~K}$. The wall edges are finished with plaster, and the door edges are sealed to prevent air infiltration in the test cell.

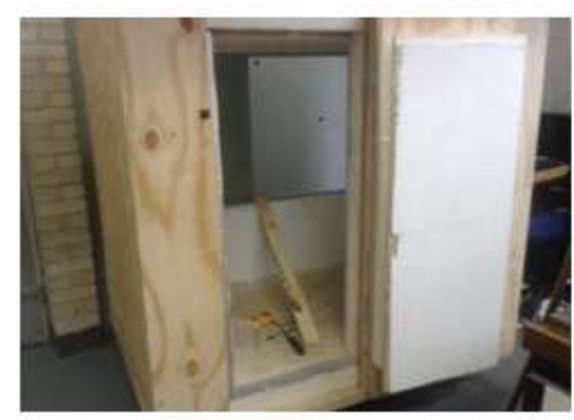

$48 \mathrm{~mm}$ wood

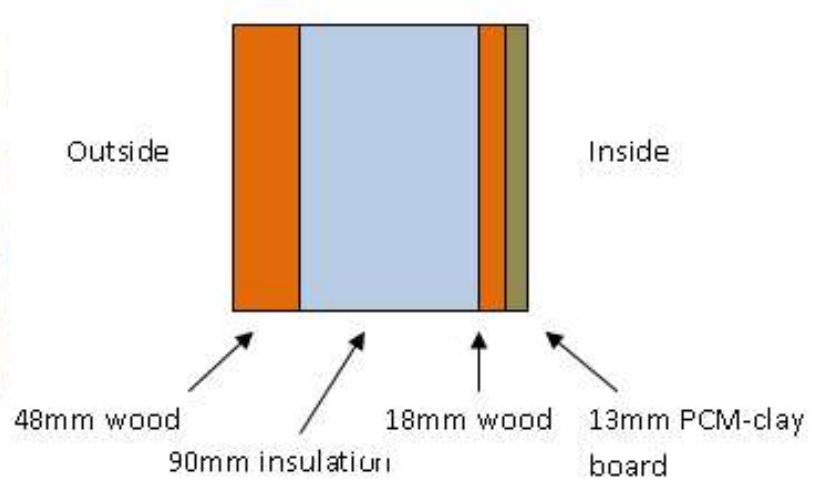

Fig. 1. Experimental test cell and Wall construction

Twenty three type $\mathrm{T}$ thermocouples were uniformly distributed inside the test cell and on the walls as shown in Fig. 2, and three thermocouples were placed at different locations inside the walls. The air sensors near the wall are located $5 \mathrm{~cm}$ from the walls and the surface sensors are covered with a thin layer of plaster. 


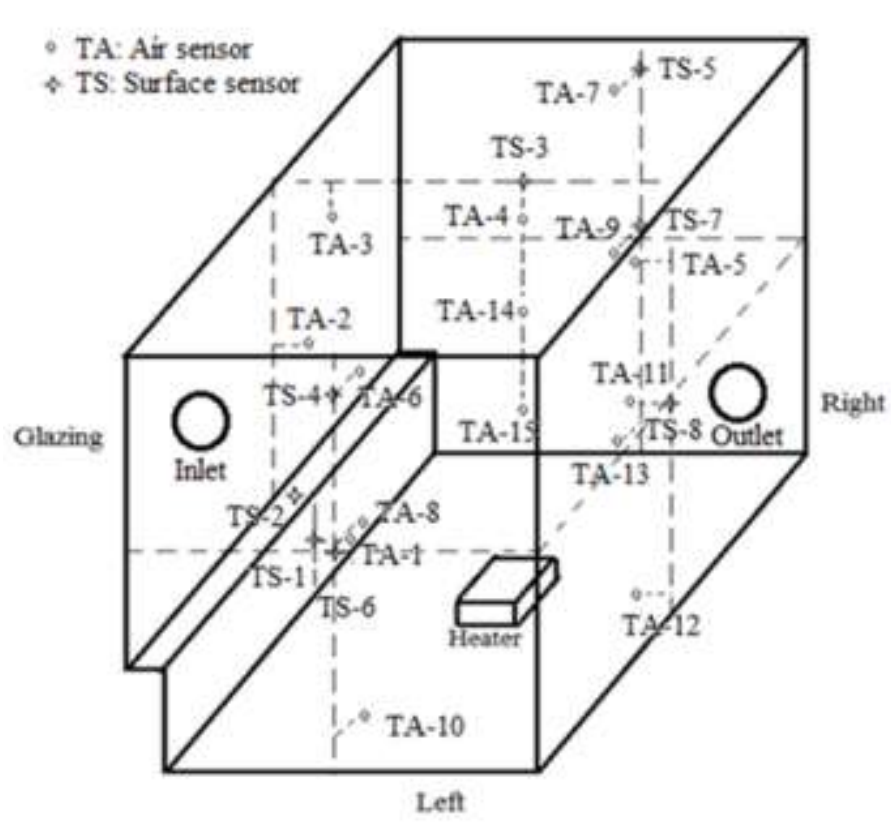

\begin{tabular}{|c|c|c|}
\hline $\begin{array}{c}\text { Thermocouple } \\
\text { symbol }\end{array}$ & $\begin{array}{c}\text { Thermocouple } \\
\text { Description }\end{array}$ & $\begin{array}{c}\text { Thermocouple } \\
\text { Uncertainty } \pm(\mathrm{K})\end{array}$ \\
\hline TA1 & Air Bottom Window & 0.2 \\
\hline TA2 & Air Centre Window & 0.2 \\
\hline TA3 & Air Top Window & 0.4 \\
\hline TA4 & Air Top Centro & 0.2 \\
\hline TA5 & Air Door Top & 0.2 \\
\hline TA6 & Air Top Left & 0.5 \\
\hline TA7 & Air Top Right & 0.2 \\
\hline TA8 & Air Mid Left & 0.2 \\
\hline TA9 & Air Mid Right & 0.2 \\
\hline TA10 & Air Bottom Left & 0.2 \\
\hline TA11 & Air Back Middle & 0.2 \\
\hline TA12 & Air Back Bottom & 0.2 \\
\hline TA13 & Air Bottom Right & 0.2 \\
\hline TA14 & Air Centre Middle & 0.2 \\
\hline TA15 & Air Centre Bottom & 0.2 \\
\hline TS1 & surface Bottom Window & 0.4 \\
\hline TS2 & Surface Window Top & 0.2 \\
\hline TS3 & Surface Top Centre & 0.3 \\
\hline TS4 & Surface Top Left & 0.4 \\
\hline TS5 & Surface Top Right & 0.2 \\
\hline TS6 & Surface Mid Left & 0.2 \\
\hline TS7 & Surface Mid Right & 0.3 \\
\hline TS8 & Surface Back Middile & 0.2 \\
\hline & & \\
\hline
\end{tabular}

Fig. 2. Location, description and uncertainty of air and surface thermocouples

This test cell was placed inside an environmental chamber where the external temperature was varied according to Fig. 3. The test cell was assumed to be an intermittently occupied building with an internal heat gain of $100 \mathrm{~W}$, provided by a $200 \mathrm{~mm} \times 100 \mathrm{~mm}$ mica plate heater during the 'daytime' hours where the external temperatures were also raised. During 'night-time' the heater was switched off, and the external temperature reduced. Two sets of experiments were performed: a non-ventilated case where the inlet and outlet were closed during night-time; and a ventilated case, where external air was blown into the test cell during night-time at a rate of $0.045 \mathrm{~kg} / \mathrm{s}$ via the $100 \mathrm{~mm}$ diameter inlet shown in Fig. 2. The air velocity is measured with the TSI hot-wire velocity meter with an accuracy of $\pm 0.015 \mathrm{~m} / \mathrm{s}$ or $3 \%$. Before each experiment was started, it was ensured that all temperatures in the cell were at the same steady value, for the valid initialization of the CFD models. Each experiment recorded data at intervals of 30s for 24 hours using Pico data loggers. 


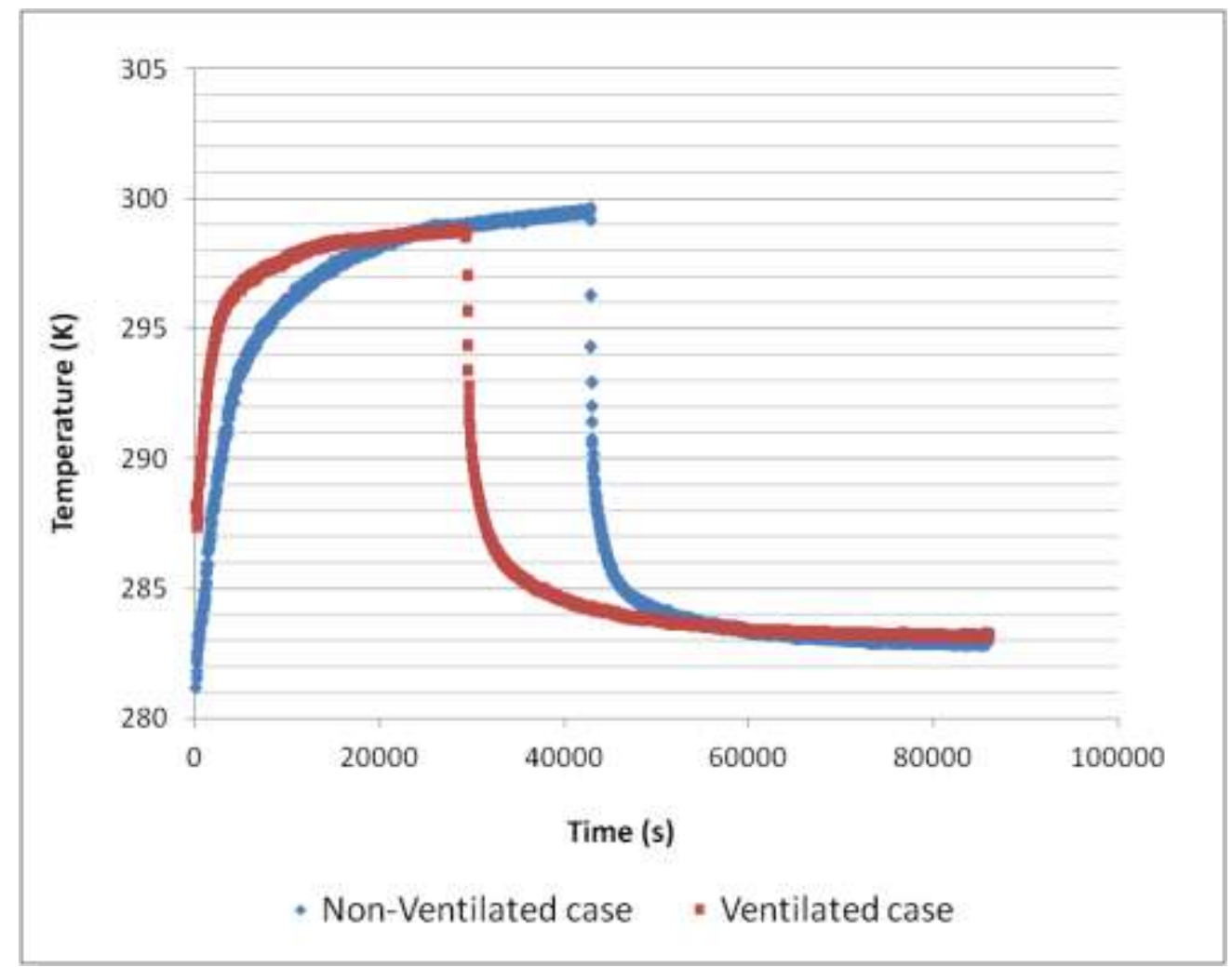

Fig. 3. Environmental chamber/ External air temperature

The external air temperature was measured with a thermocouple of accuracy $\pm 0.2 \mathrm{~K}$, and was implemented in the simulation as the equation of a curve with uncertainty $\pm 0.1 \mathrm{~K}$. The uncertainties of all thermocouples in Fig. 2 are constant for the temperature range in this study and include the errors due to the data-loggers.

Due to the relatively small area of the heater, the low emissivity of the zinc-coated steel casing $(\varepsilon \approx 0.1)$ and the quasi-constant surface temperature of $120-140{ }^{\circ} \mathrm{C}, 3.5 \mathrm{~W}$ of radiative power is emitted by the heater. No external sources of radiation were present during the experiments. Furthermore, due to symmetry of the test cell walls and the stratification phenomenon inside the cell, the highest experimental wall temperature difference was found to be between the ceiling $(\approx 301 \mathrm{~K})$ and the floor $(\approx 297 \mathrm{~K})$. Based on these data and the emissivity of wood $(\approx 0.8)$ [26], the maximum radiative power between the floor and ceiling was found to be $15 \mathrm{~W}$. Therefore, in effect, as the experimental radiative power in the cell was calculated to vary between $3.5 \%$ and $18 \%$ of the total heater 
power during the transient tests, the effects of radiation were neglected to simplify the modelling. The impact of this is discussed in section 4.

These scenarios mimic an intermittently occupied building, with an internal gain of $100 \mathrm{~W} / \mathrm{m}^{2}$ and a large glazed area, without external radiation, where normal plasterboards have been replaced by PCM boards. These boards are mainly used to reduce temperature swings and limit excessive temperatures in lightweight buildings during summer. The ventilated and non-ventilated cases relate to the method of charging the PCM boards at night, to restore their cooling potential [1]. These scenarios will therefore provide comparative data on the effectiveness of the PCM board during the day, and with/without night ventilation.

\subsection{PCM board}

The PCM board investigated in this study is a commercial $13 \mathrm{~mm}$ Clay board impregnated with $21 \%$ (by volume) Micronal ${ }^{(R)}$ PCM. These EBB ${ }^{\text {TM }}$ PCM boards are manufactured by mixing the PCM microcapsules and clay, before being compacted and embedded in a polythene matrix. The boards are an eco-friendly alternative to gypsum plasterboards, with the PCM preventing overheating and reducing the temperature swings in thermally lightweight buildings. The properties of the materials are given in Table 1.

\begin{tabular}{|c|c|c|c|c|c|}
\hline Properties & $\begin{array}{c}\text { PCM } \\
\text { board }\end{array}$ & Wood & $\begin{array}{c}\text { Rigid PIR } \\
\text { Insulation }\end{array}$ & $\begin{array}{c}\text { Glazing - 24mm } \\
\text { (90\% Ar filled) }\end{array}$ & Plaster \\
\hline Density $\left(\mathrm{kg} / \mathrm{m}^{3}\right)$ & 1430 & 500 & 40 & 140 & 950 \\
\hline Specific heat capacity $(\mathrm{J} / \mathrm{kgK})$ & 1240 & 1300 & 1600 & 840 & 840 \\
\hline Thermal conductivity $(\mathrm{W} / \mathrm{mK})$ & 0.14 & 0.13 & 0.023 & 0.03 & 0.16 \\
\hline
\end{tabular}

Table 1. Material properties from manufacturer

\subsubsection{Phase change characteristics of PCM board}

The melting and freezing behaviours of the PCM board were analysed by the Perkin Elmer DSC 6000. 


\begin{tabular}{|c|c|c|c|c|c|c|}
\hline \multirow{2}{*}{$\begin{array}{l}\text { Heating / } \\
\text { cooling } \\
\text { Rate }\end{array}$} & \multicolumn{3}{|c|}{ Melting } & \multicolumn{3}{|c|}{ Freezing } \\
\hline & $\begin{array}{c}\text { Onset } \\
\text { Temperature } \\
\text { (K) }\end{array}$ & $\begin{array}{c}\text { End } \\
\text { Temperature } \\
\text { (K) }\end{array}$ & $\begin{array}{c}\text { Enthalpy } \\
(\mathrm{kJ} / \mathrm{kg})\end{array}$ & $\begin{array}{c}\text { Onset } \\
\text { Temperature } \\
\text { (K) }\end{array}$ & $\begin{array}{c}\text { End } \\
\text { Temperature } \\
\text { (K) }\end{array}$ & Enthalpy $(\mathrm{kJ} / \mathrm{kg})$ \\
\hline \multicolumn{7}{|c|}{$1^{\text {st }}$ Sample (S-1) } \\
\hline $0.5 \mathrm{~K} / \mathrm{min}$ & 285.4 & 295.5 & 14.7 & 295.4 & 284.4 & 17.0 \\
\hline $1 \mathrm{~K} / \mathrm{min}$ & 285.3 & 295.5 & 14.8 & 295.3 & 284.2 & 17.1 \\
\hline $2 \mathrm{~K} / \mathrm{min}$ & 284.9 & 296.0 & 15.6 & 294.8 & 283.8 & 17.7 \\
\hline \multicolumn{7}{|c|}{$2^{\text {nd }}$ Sample (S-2) } \\
\hline $0.5 \mathrm{~K} / \mathrm{min}$ & 284.9 & 296.1 & 16.3 & 294.9 & 284.9 & 17.9 \\
\hline $1 \mathrm{~K} / \mathrm{min}$ & 284.8 & 295.9 & 16.3 & 294.9 & 284.8 & 18.0 \\
\hline $2 \mathrm{~K} / \mathrm{min}$ & 284.1 & 296.4 & 17.0 & 293.8 & 283.8 & 18.8 \\
\hline \multicolumn{7}{|c|}{$3^{\text {rd }}$ Sample (S-3) } \\
\hline $0.5 \mathrm{~K} / \mathrm{min}$ & 285.2 & 295.8 & 15.6 & 295.2 & 284.7 & 17.4 \\
\hline $1 \mathrm{~K} / \mathrm{min}$ & 285.1 & 295.9 & 15.7 & 295.1 & 284.6 & 17.5 \\
\hline $2 \mathrm{~K} / \mathrm{min}$ & 284.5 & 296.3 & 16.1 & 294.6 & 283.8 & 18.5 \\
\hline \multicolumn{7}{|c|}{ Enthalpy Porosity Model } \\
\hline- & 284.9 & 295.5 & 16.5 & 295.5 & 284.9 & 16.5 \\
\hline
\end{tabular}

Table 2. PCM DSC enthalpy, onset and end temperatures for different samples and heating/cooling rates

The DSC was calibrated by Perkin Elmer ${ }^{\circledR}$ with Indium and Zinc standards, using a two point-calibration method. The DSC has an accuracy of $\pm 0.1 \mathrm{~K}$ for temperature and $\pm 2 \%$ for the phase change enthalpy $\left(\Delta \mathrm{h}_{\mathrm{DSC}}\right)$, based on the overall melting/freezing range [27]. Table 2 shows the DSC results obtained from 3 random samples taken at different areas in the boards, at heating/cooling rates of $0.5 \mathrm{~K} / \mathrm{min}, 1 \mathrm{~K} / \mathrm{min}$ and $2 \mathrm{~K} / \mathrm{min}$ [28]. It shows that as the heating/cooling rate of each sample is lowered, the melting/ freezing enthalpy, and phase change temperatures tend towards a constant value. The lowest investigated heating/cooling rate of $0.5 \mathrm{~K} / \mathrm{min}$ provides values which are within the uncertainty of $\pm 0.1 \mathrm{~K}$ and $\pm 2 \%$ of the enthalpy change for the DSC, and are therefore considered for further analysis. Between the 3 samples at $0.5 \mathrm{~K} / \mathrm{min}$, a mean melting enthalpy of $15.6 \mathrm{~kJ} / \mathrm{kg}$ and mean freezing enthalpy of $17.4 \mathrm{~kJ} / \mathrm{kg}$ are obtained, with a deviation of $\pm 0.9 \mathrm{~kJ} / \mathrm{kg}$ between samples. A mean melting onset temperature of $285.2 \mathrm{~K}$, and end temperature of $295.8 \mathrm{~K}$ are 
obtained, while a mean freezing onset temperature of $295.2 \mathrm{~K}$ and end temperature of $284.7 \mathrm{~K}$ are obtained. The deviation in temperature between the 3 samples is $\pm 0.6 \mathrm{~K}$. These deviations can be attributed to the non-uniform PCM concentration in the PCM-Clay board. The enthalpy-porosity model is defined as the average values of the onset and end temperatures, and enthalpy of all the samples at $0.5 \mathrm{~K} / \mathrm{min}$ for both freezing and melting.

Fig. 4 shows the melting and freezing curves for the enthalpy porosity model, and S-3 sample at a rate of $0.5 \mathrm{~K} / \mathrm{min}$. It also portrays the hysteresis effect described in section 1.2 and Table 2 (Note that the enthalpy-temperature curvatures of all samples are similar).

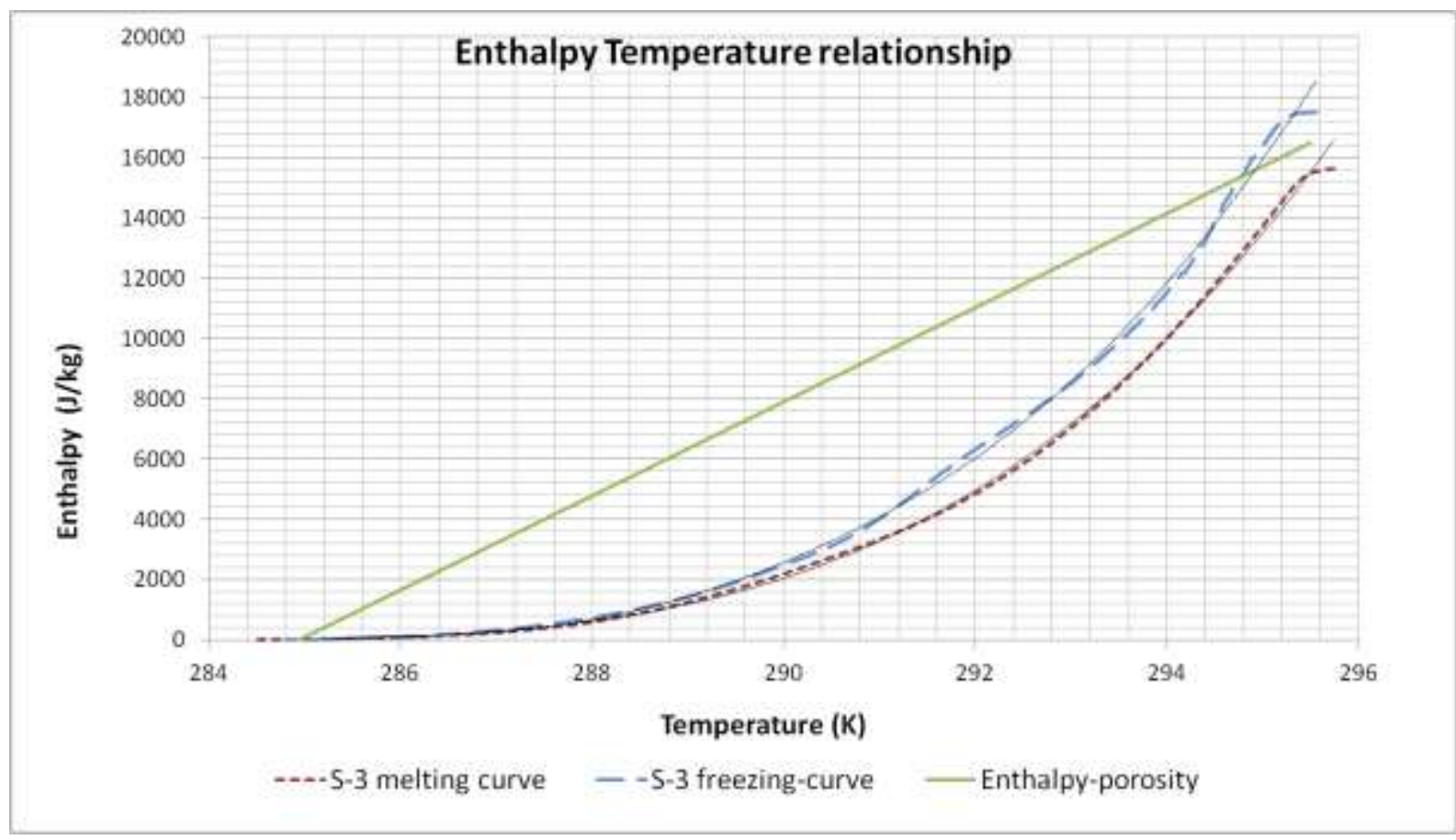

Fig. 4. Melting and freezing curves of sample S-3 and the enthalpy-porosity model

The enthalpy-porosity model deviates from the average DSC melting and freezing enthalpy by a maximum of $5 \mathrm{~kJ}$, and $\pm 0.6 \mathrm{~K}$ from the average sample temperatures.

As the UDF enthalpy-temperature relationships of the samples are incorporated in the simulations as the equations of curves, there are some uncertainties associated with the curve fitting of the experimental DSC data. Table 3 shows the uncertainty in enthalpy 
associated with the curve fitting ( $\Delta \mathrm{h}_{\text {curve-fit }}$ ) of the experimental DSC data for different samples over the phase change range. This is obtained through the comparison of the DSC data and data calculated by the curve-fit equation. Table 3 also shows the total uncertainty in the enthalpy data, defined by Eq. 5 .

$$
\Delta \mathrm{h}_{\text {total }}=\Delta \mathrm{h}_{\text {curve-fit }}+\Delta \mathrm{h}_{\mathrm{DSC}} \quad \text { - Eq. (5) }
$$

\begin{tabular}{|c|c|c|c|c|c|c|}
\hline & \multicolumn{3}{|c|}{ Melting } & \multicolumn{3}{c|}{ Freezing } \\
\hline & $\mathrm{R}^{2}$ & $\Delta \mathrm{h}_{\text {curve-fit }}$ & $\Delta \mathrm{h}_{\text {total }}$ & $\mathrm{R}^{2}$ & $\Delta \mathrm{h}_{\text {curve-fit }}$ & $\Delta \mathrm{h}_{\text {total }}$ \\
\hline Sample-1 (S-1) & 0.999 & $\pm 0.065 \mathrm{~kJ} / \mathrm{kg}$ & $\pm 0.360 \mathrm{~kJ} / \mathrm{kg}$ & 0.998 & $\pm 0.350 \mathrm{~kJ} / \mathrm{kg}$ & $\pm 0.700 \mathrm{~kJ} / \mathrm{kg}$ \\
\hline Sample-2 (S-2) & 0.999 & $\pm 0.073 \mathrm{~kJ} / \mathrm{kg}$ & $\pm 0.400 \mathrm{~kJ} / \mathrm{kg}$ & 0.998 & $\pm 0.343 \mathrm{~kJ} / \mathrm{kg}$ & $\pm 0.700 \mathrm{~kJ} / \mathrm{kg}$ \\
\hline Sample-3 (S-3) & 0.999 & $\pm 0.061 \mathrm{~kJ} / \mathrm{kg}$ & $\pm 0.370 \mathrm{~kJ} / \mathrm{kg}$ & 0.998 & $\pm 0.340 \mathrm{~kJ} / \mathrm{kg}$ & $\pm 0.690 \mathrm{~kJ} / \mathrm{kg}$ \\
\hline
\end{tabular}

Table 3. Regression coefficient, enthalpy uncertainty in $\mathrm{h}-\mathrm{T}$ curve fits and total uncertainty in enthalpy at heating/cooling rate of $0.5 \mathrm{~K} / \mathrm{min}$

Table 3 shows that the uncertainty associated with the curve fitting $\left(\Delta \mathrm{h}_{\text {curve-fit }}\right)$ varies in the range of $0.06-0.35 \mathrm{~kJ} / \mathrm{kg}$, and as can be inferred from Fig. 4 , it is more prominent at higher temperatures. The total uncertainty $\left(\Delta h_{\text {total }}\right)$ indicates how close the curve-fit data used in the simulation are to the real values. The uncertainty values are relatively low compared to the enthalpy hysteresis effect of each sample from Table 2 (i.e. the difference between melting and freezing enthalpy), but are comparable to the deviation in enthalpies between the 3 samples. Thus for completeness, the validation study was done with all 3 samples at a rate of $0.5 \mathrm{~K} / \mathrm{min}$, to investigate their influence on the final results. The uncertainty in temperatures $( \pm 0.1 \mathrm{~K})$ associated with the DSC apparatus is small relative to the phase change temperature range. The equations of the melting and freezing curves for S-3 (to 2 decimal places) are given as examples by Eq. (6) and (7), with units of J/kg.

$$
\begin{array}{lll}
S_{E, m}=12.78 T^{3}-10932.54 T^{2}+3117074.92 T-296256708.90 & \left(R^{2}=0.999\right) & - \text { Eq. (6) } \\
-S_{E, f}=13.02 T^{3}-11055.07 T^{2}+3129090.90 T-295246573.26 & \left(R^{2}=0.998\right) & - \text { Eq. (7) }
\end{array}
$$




\subsection{Validation of CFD models}

The performance of PCM in buildings is mainly related to the temperature peak shifts and the time period under which the passive PCM boards limit excessive temperatures in the building, making the phase change simulation a transient problem. As a result, the validation study performed in ANSYS ${ }^{\circledR}$ FLUENT 13.0 is based on the dynamic evolution of temperature at various points in the test-cell, compared to the corresponding experimental data. Validation has been divided into two sections: a non-ventilated and a ventilated case, and the simulations are replica of the actual experimental setup. The phase change models described in 2.2.1 are implemented in the FLUENT code as User Defined Functions.

\subsection{Numerical Considerations}

The external surfaces of the test-cell are bounded by convective heat transfer conditions. The steady external convective heat transfer coefficients were determined by a separate CFD investigation, modelling the external surface of the test-cell and the environmental chamber. This resulted in values of $5.3 \mathrm{~W} / \mathrm{m}^{2} \mathrm{~K}$ for the bottom and right surfaces, $2.8 \mathrm{~W} / \mathrm{m}^{2} \mathrm{~K}$ for the glazing, left and top surfaces, and $2.4 \mathrm{~W} / \mathrm{m}^{2} \mathrm{~K}$ for the back surface, with reference to Fig. 2. A heat generation rate of $500,000 \mathrm{~W} / \mathrm{m}^{3}$ is applied to model the $10 \mathrm{~mm}$ thick plate heater. The mass-flow inlet and pressure outlet are closed during the non-ventilated cases. The RNG k- $\varepsilon$ turbulence model, with non-slip enhanced wall functions were used and air was considered as an ideal gas. Body-force weighted discretisation scheme was employed for pressure, and second order upwind scheme was used for momentum, density and energy. The SIMPLE algorithm was used for the pressure-velocity coupling. The material properties of the wall are given in Table 1. 
Being a transient simulation, the spatial and temporal convergence stability of the mesh was studied based on the $L_{2}$ norm for temperature and velocity. The $L_{2}$ norm quantifies errors based on the difference between the exact solution of the governing differential equations and the solution of the discrete equations, as shown by Eq. (8) [29]. As the exact solution of the governing equations is not known, the results of a simulation with a uniformly very fine mesh $(850,000$ elements) and time step (10s) were taken as the benchmark [30]. Three meshes: coarse (140,000 elements); medium (212,500 elements); and fine (283,000 elements), and three time-steps: 500s; 200s; and 100s were considered in this independence study. Mesh refinement was performed by varying all mesh sizes by the same ratio, but maintaining the inflation parameters.

$$
\mathrm{L}_{2} \operatorname{norm}=\left[\frac{\sum\left[V_{i}\left(\phi_{\text {discrete }}-\phi_{\text {exact }}\right)_{i}^{2}\right]}{\sum V_{i}}\right]^{1 / 2}
$$

The $L_{2}$ norm was computed for uniformly distributed points, $0.2 \mathrm{~m}$ apart, over the three planes (across the inlet, outlet and heater) shown in Fig. 5, and for 1000 s intervals for the ventilated case, which consists of both buoyancy driven and forced convection flows. The default FLUENT residual convergence criteria were employed for all simulations. 


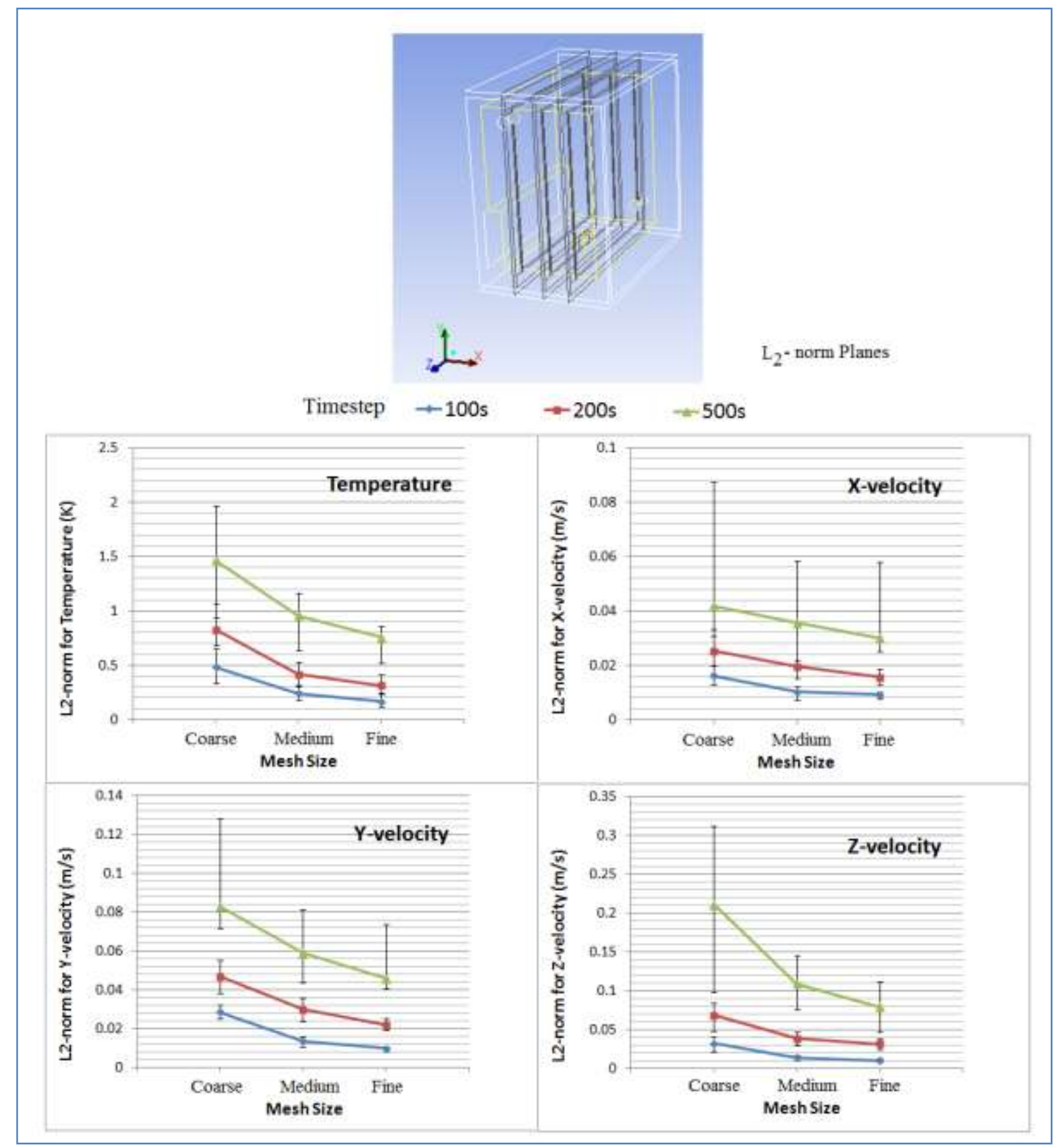

Fig. 5. $L_{2}$-planes and $L_{2}$-norm for temperature and velocities

Fig. 5 shows that the temperature and velocity norms are more dependent on the time-step than the mesh size. A temperature convergence criteria of $0.2-0.4 \mathrm{~K}$ was used, based on the uncertainty of the thermocouples, while $0.015 \mathrm{~m} / \mathrm{s}$ was used for the velocity convergence criteria based on the accuracy of the TSI velocity meter used in the experiment. Under these conditions, the temperature criterion is satisfied with the Fine100s, Fine-200s and Medium-100s setups, and the velocity criterion is satisfied by the 
Medium-100s and Fine-100s setups. Thus to minimise computational time, the Medium100s setup was employed for the simulations. Both the ventilated and non-ventilated cases were simulated on the same grid with an average $y+$ value of 6 . The employed mesh is shown in Fig. 6.

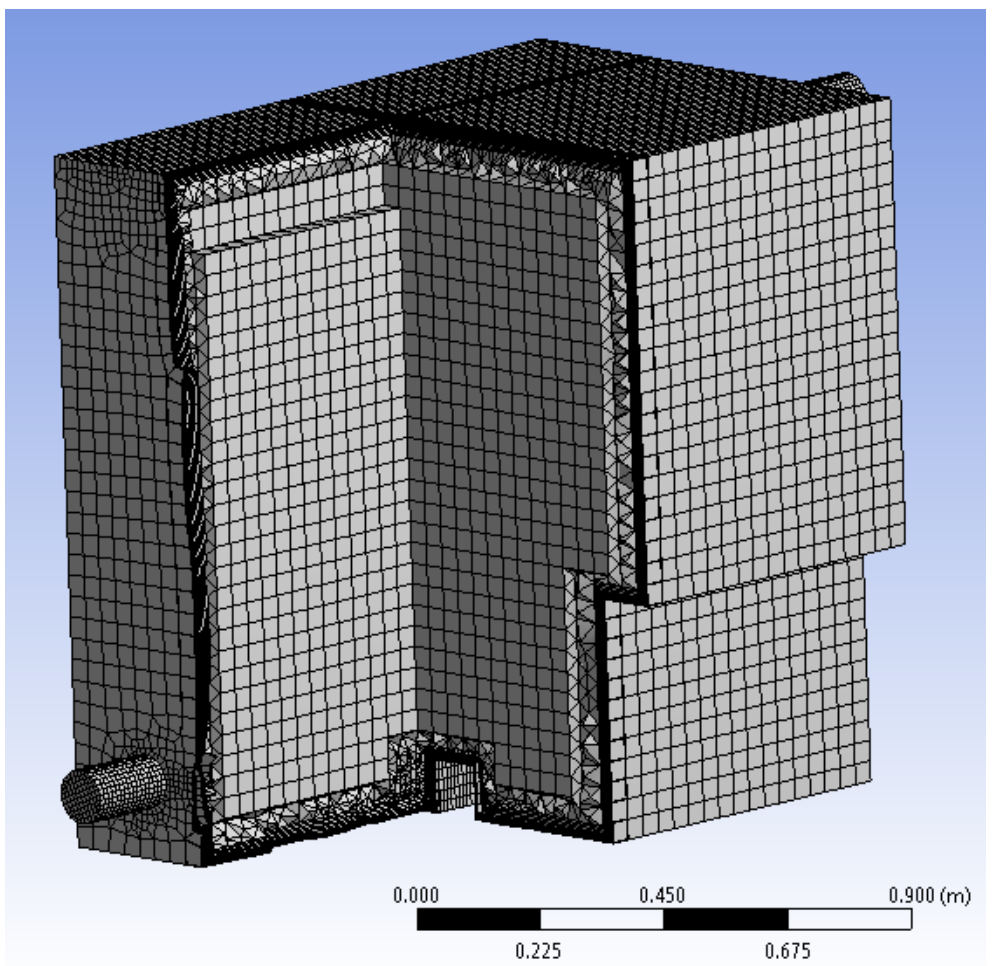

Fig. 6(a). Mesh in main air-domain

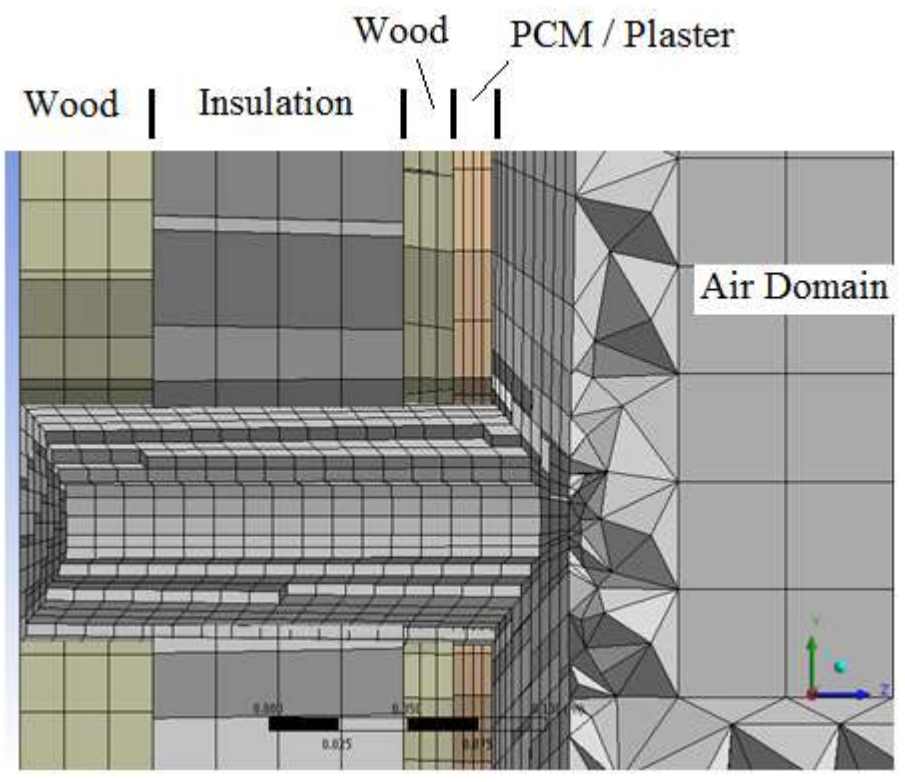

Fig. 6(b). Mesh distribution in walls and air boundary layer 
The mesh was designed using the in-built ANSYS design modeller meshing algorithm, and the resulting mesh comprised of hexahedral cells in the near-wall inflated layers and wall domains, with tetrahedral and hexahedral cells in the air domain, as shown in Fig. 6. Eight inflation layers were used near the walls, with a first grid size of $2 \mathrm{~mm}$ and growth ratio of 1.3. The mesh size increases towards the bulk of the air domain to $40 \mathrm{~mm}$. The walls contain 3-4 mesh intervals along the thickness, with a face cell size of $20-50 \mathrm{~mm}$. The inlet and outlet domains contains four inflation layers with a first grid size of $1.5 \mathrm{~mm}$, growth ratio of 1.2 and an average of $10 \mathrm{~mm}$ cells in the main fluid flow. The mesh at the heater has a face size of $10 \mathrm{~mm}$ and 8 inflation layers with a first grid size of $1.5 \mathrm{~mm}$ and growth ratio of 1.1.

\subsection{Non-Ventilated case}

In this case, the test cell was initialised from $281 \mathrm{~K}$. The external temperature varied according Fig. 3, where $100 \mathrm{~W}$ was applied to the heater, mimicking a building during daytime. Night-time was simulated after $12 \mathrm{hrs}$ by turning off the heaters, and lowering the external air temperature back to $283 \mathrm{~K}$, completing a cycle. The total simulation time for one phase change cycle was $9.1 \mathrm{hrs}$ with an i7 $-2.93 \mathrm{GHz}$ processor, working with 4 parallel cores

\subsubsection{Validation Results}

Fig. 7 shows the experimental and simulated temperatures of 3 generic thermocouples in the test-cell, using the three PCM samples and the enthalpy porosity model for the nonventilated scenario. The complete error analysis is given in Fig. 8 . 


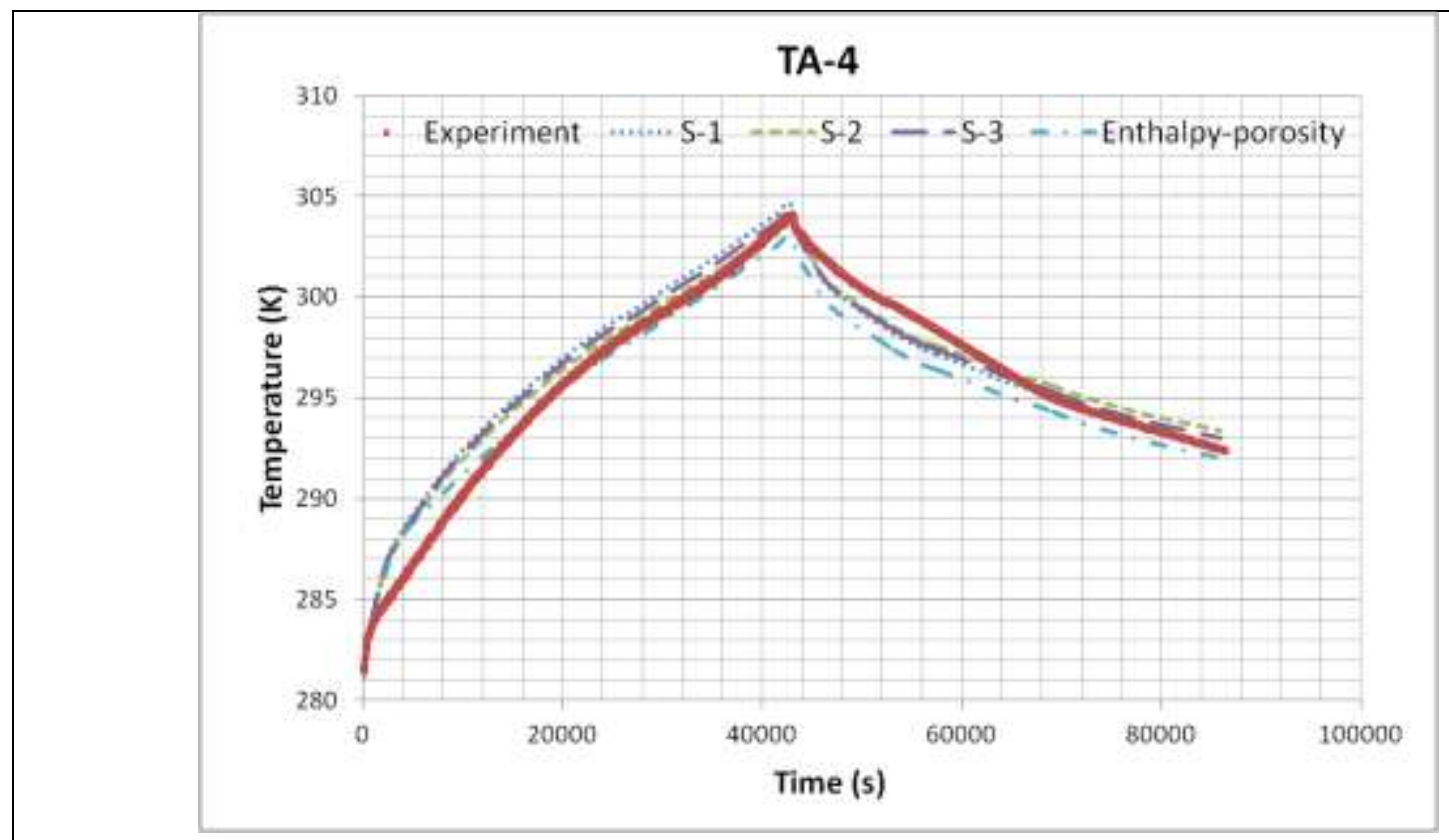

Fig. 7(a). TA-4 Non-ventilated experimental and simulated temperatures

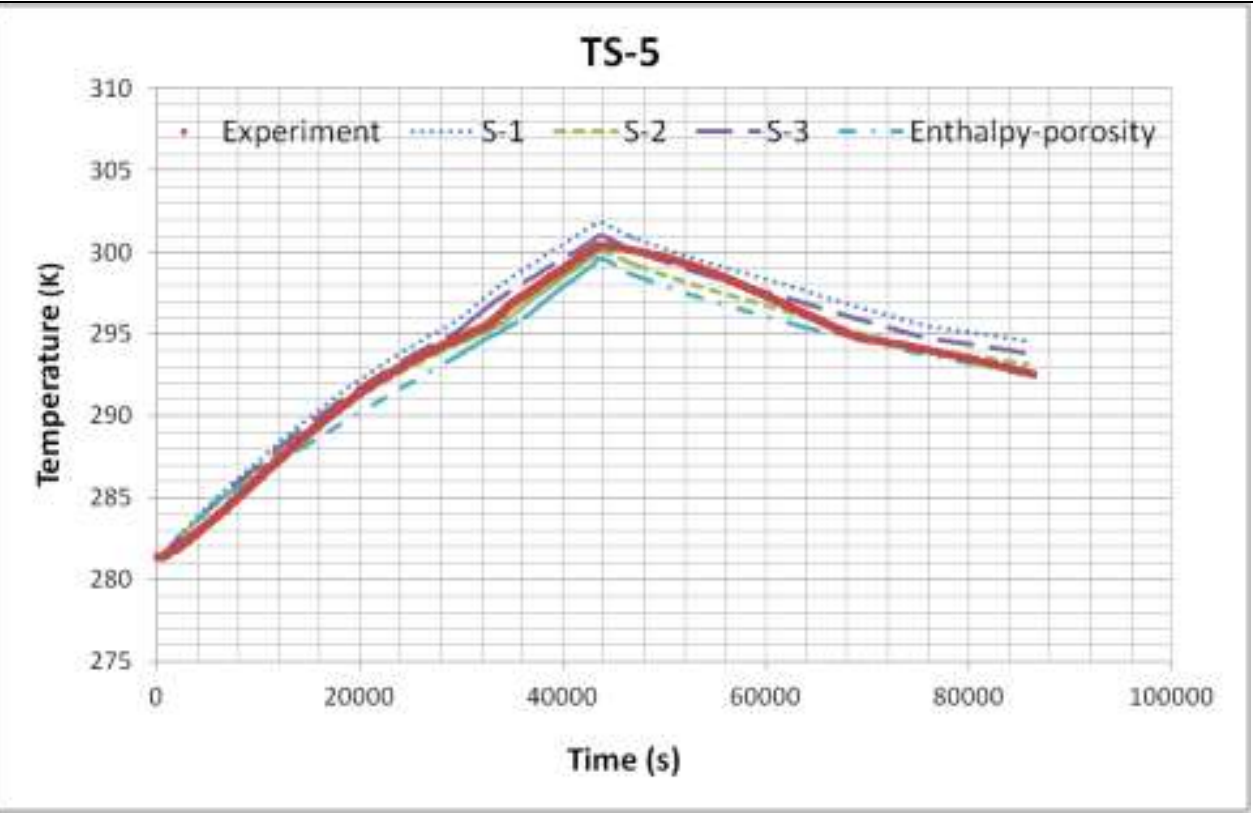

Fig. 7(b). TS-5 Non-ventilated experimental and simulated temperatures 


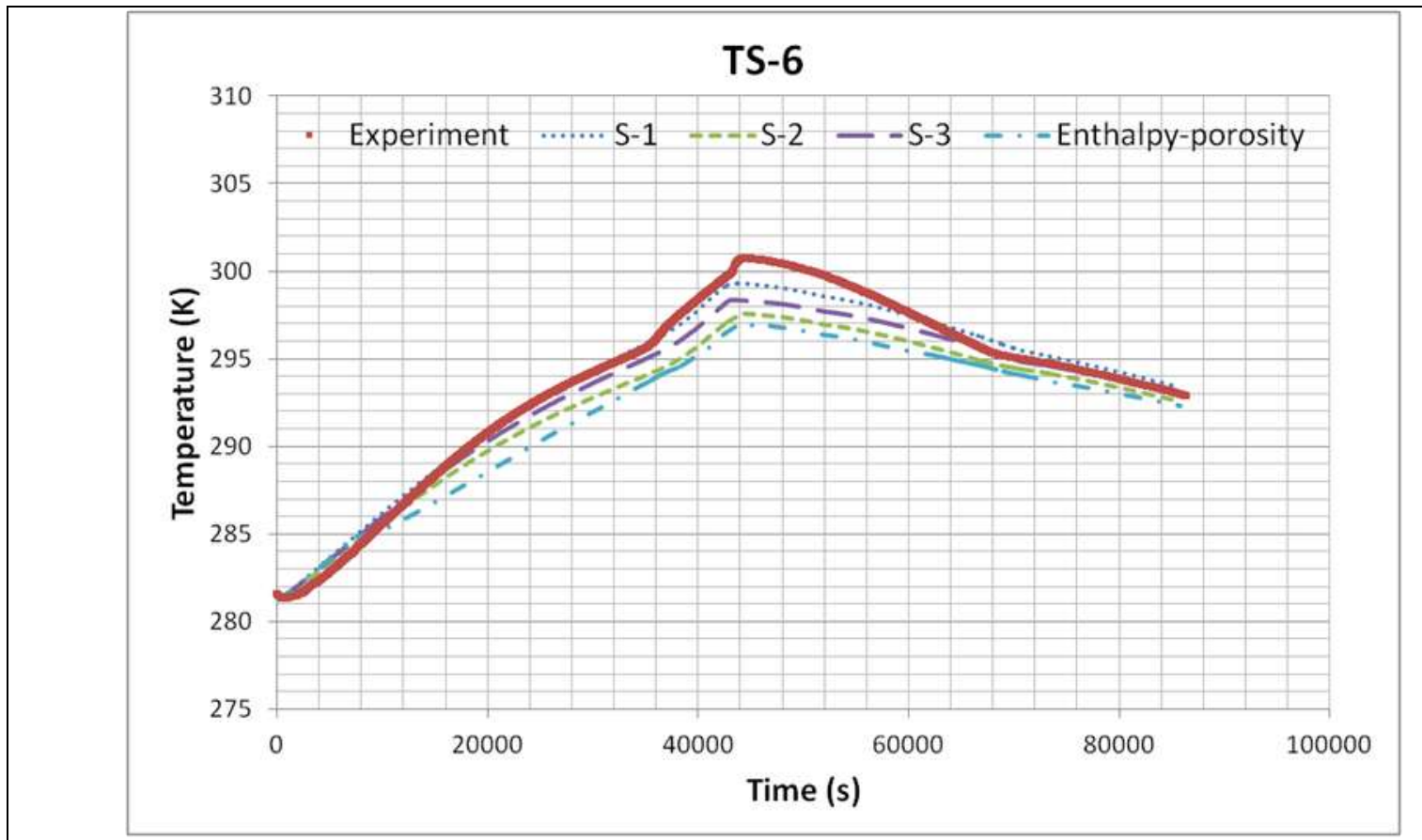

Fig. 7(c). TS-6 Non-ventilated experimental and simulated temperatures

Figs. 7 depict that different phase change models provide different temperature trends, and different errors in comparison to the experimental data. Nonetheless, the overall progression of temperature is valid in all cases. The errors are quantified in terms of the absolute RMS (Root Mean Square) error and the relative RMS error between the numerical and experimental data, calculated using Eq. (9).

$$
\text { Relative RMS Error }=\frac{\text { Overall Local Absolute RMS error } * 100}{\text { Smallest Peak Local Experimental Temperature difference }} \quad \text { - Eq. } 9
$$

The relative RMS error represents the overall local relative error in the transient simulation and is based on the smallest peak local experimental temperature difference obtained during the test cell heating/cooling cycle. This calculation method is analogous to the validation procedure used in [16], where the authors based the steady state relative errors on the temperature difference between the outlet/inlet, local/environment or cold/hot surfaces. However due to the transient nature of this study, the relative errors are 
hereby defined in a different way. The smallest local experimental temperature difference in Eq. (9), is the difference between the start/peak or peak/end temperatures of the experiment, where the 'small' nature of the difference provides a more conservative error evaluation. Thus in this non-ventilated case, the denominator in Eq. (9) is the difference between the local peak and the end experimental temperatures in the cycle, that is, the smallest difference for each thermocouple.

Fig. 8 shows a more detailed description of the errors for each thermocouple. Note that the errors include the uncertainties of the respective thermocouples, which are constant for the temperature range in this study.

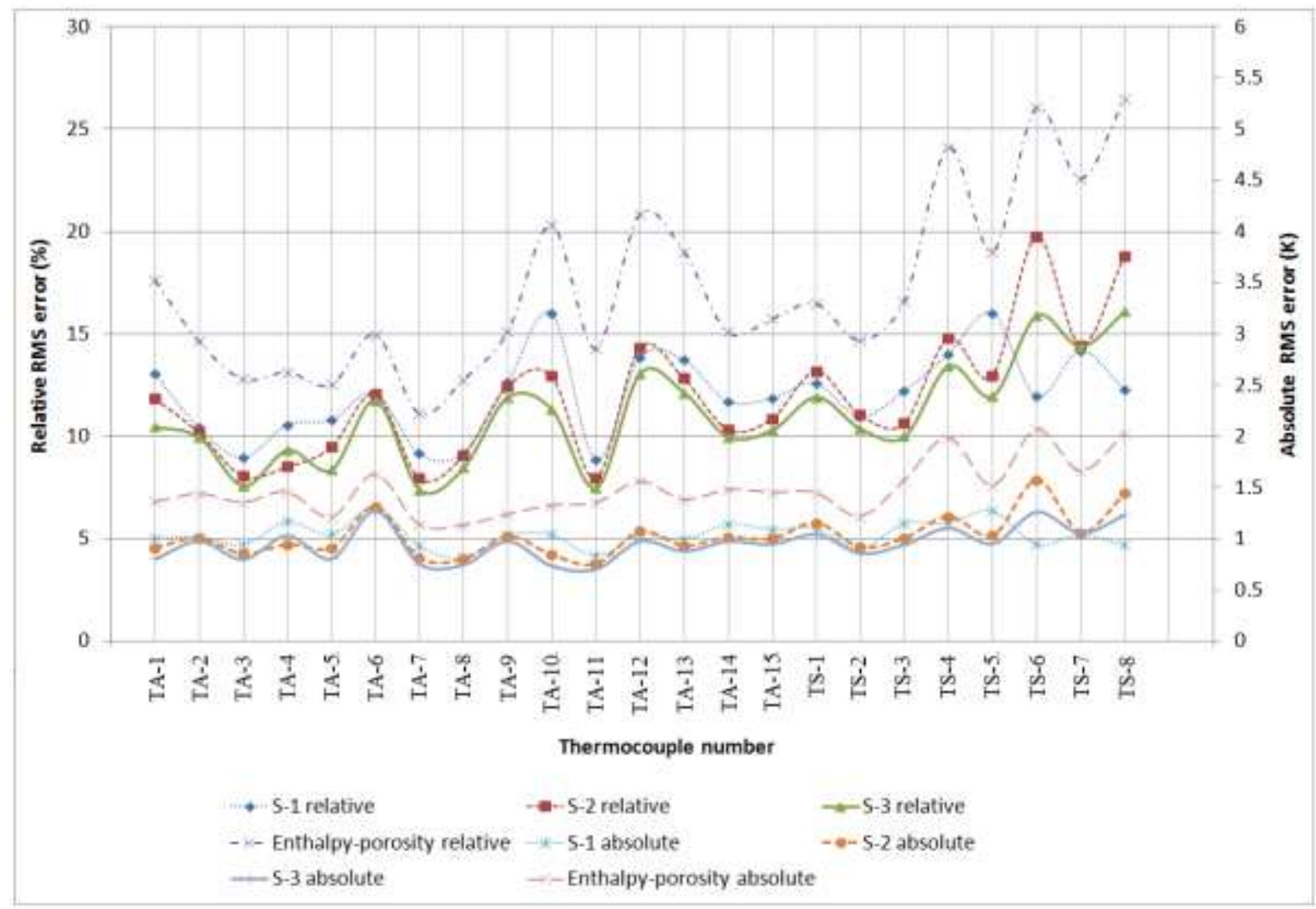

Fig. 8. Local error analysis for non-ventilated scenario

The absolute errors vary between $0.7-1.5 \mathrm{~K}$ and $0.8-2.1 \mathrm{~K}$, corresponding to relative errors of $7.3-20.8 \%$ and $8.5-27 \%$, for the air and surface temperatures, respectively. The 
higher errors for surface temperatures can be attributed to the uneven distribution of PCM in the boards. Overall average errors of $11.92 \%(1.07 \mathrm{~K}), 11.73 \%(1.02 \mathrm{~K})$ and $10.8 \%(0.96 \mathrm{~K})$ are obtained for sample-1, sample-2 and sample-3, respectively. It can also be seen from Fig. 8 that the enthalpy-porosity model produces higher errors of $11-27 \%$, with an average of $18.5 \%(1.5 \mathrm{~K})$, than the method that incorporates the hysteresis effects in the PCM simulation. As the relative errors are lower than $30 \%$ and using a similar justification as proposed in [16], it can be claimed that the validation of the CFD modelling study is acceptable.

\subsection{Ventilated case}

In this case, the test cell was initialised from $287.5 \mathrm{~K}$, with the external air temperature increasing with the $100 \mathrm{~W}$ heater turned on for $8.2 \mathrm{hrs}$ simulating day-time. Night-time was simulated by turning off the heaters, and lowering the external air temperature back to 283 $\mathrm{K}$, as in Fig. 3. Night-time is supplemented by an axial fan blowing external air into the testcell at a rate of $0.045 \mathrm{~kg} / \mathrm{s}$ through the inlet. The total simulation time was $11.3 \mathrm{hrs}$ with an i7 - 2.93GHz processor, working with 4 parallel cores.

\subsubsection{Validation Results}

Fig. 9 shows the experimental and simulated temperatures of 3 generic thermocouples in the test-cell using data from the three samples and the enthalpy porosity model, for the non-ventilated scenario. The complete error analysis is given in Fig. 10. 


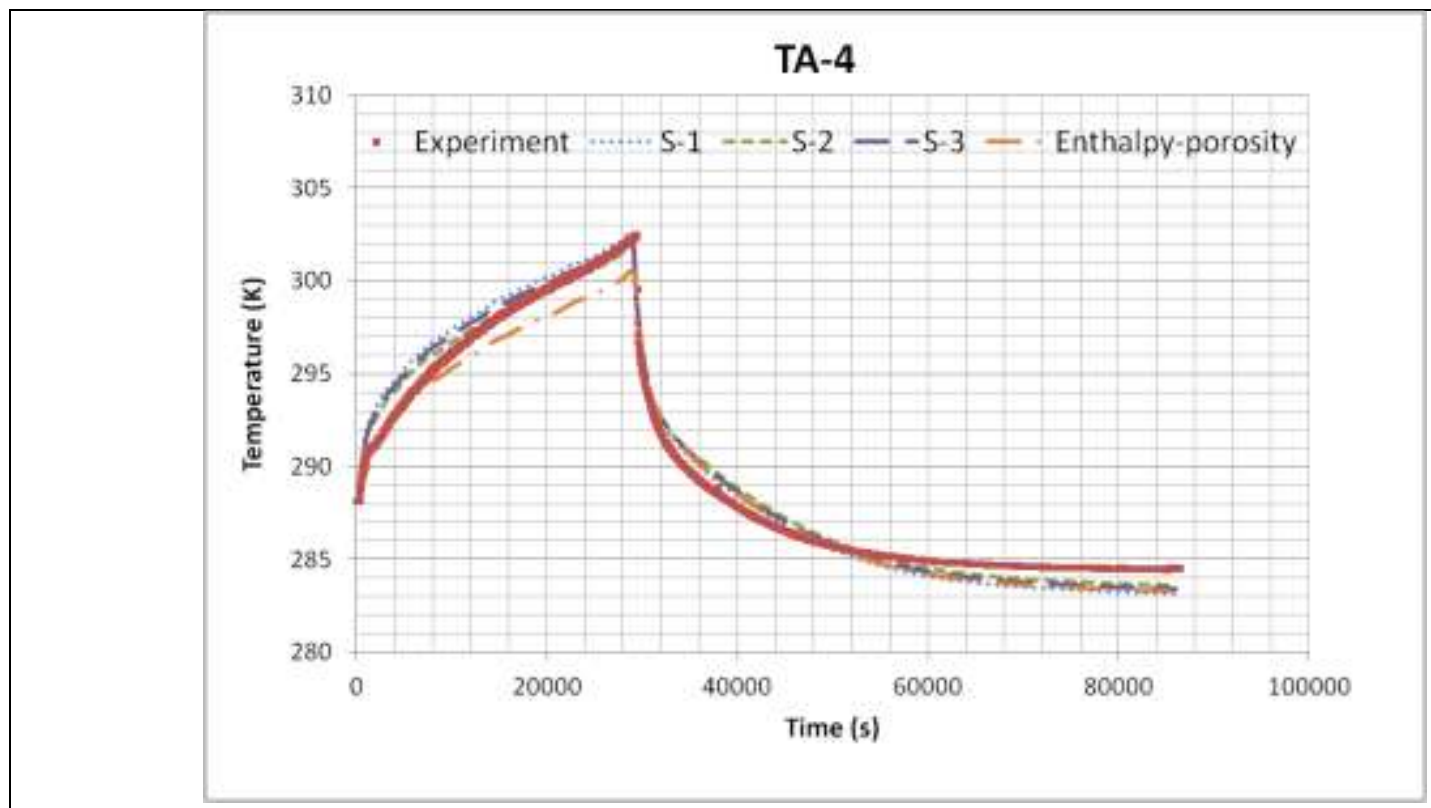

Fig. 9(a). TA-4 Ventilated experimental and simulated temperatures

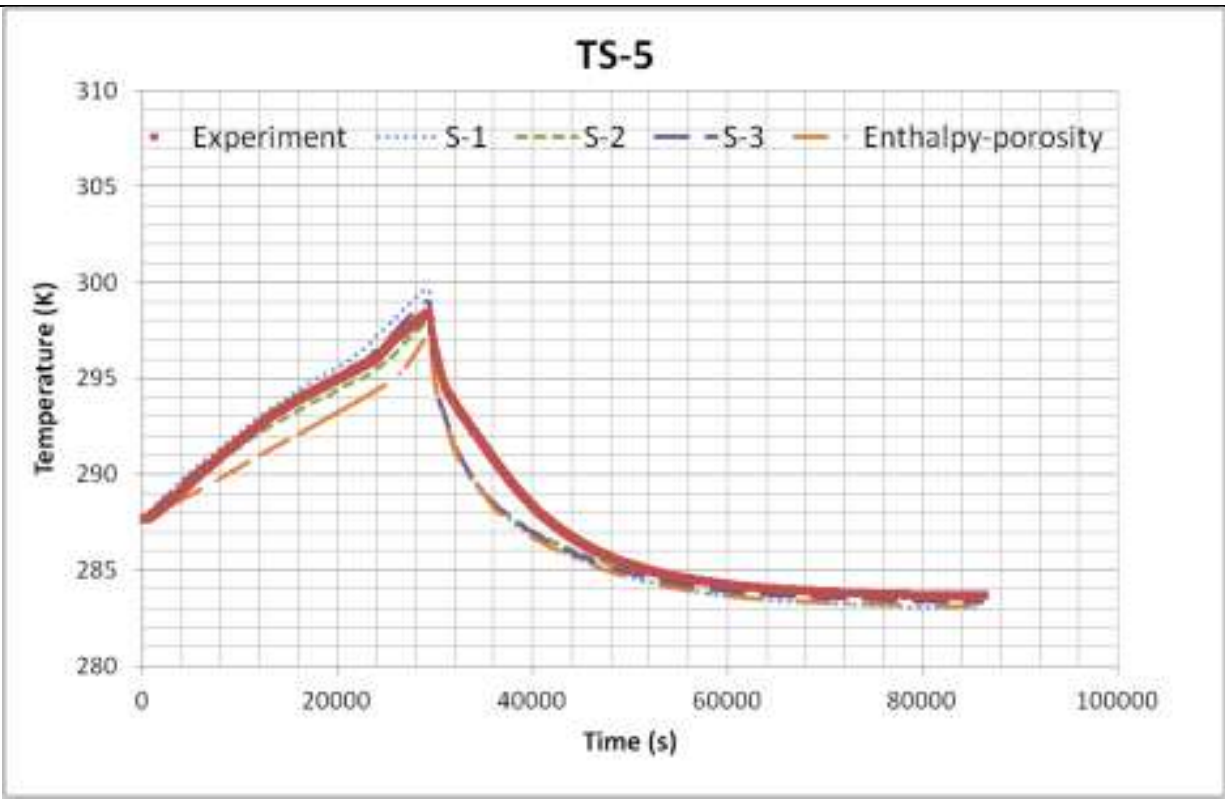

Fig. 9(b). TS-5 Ventilated experimental and simulated temperatures 


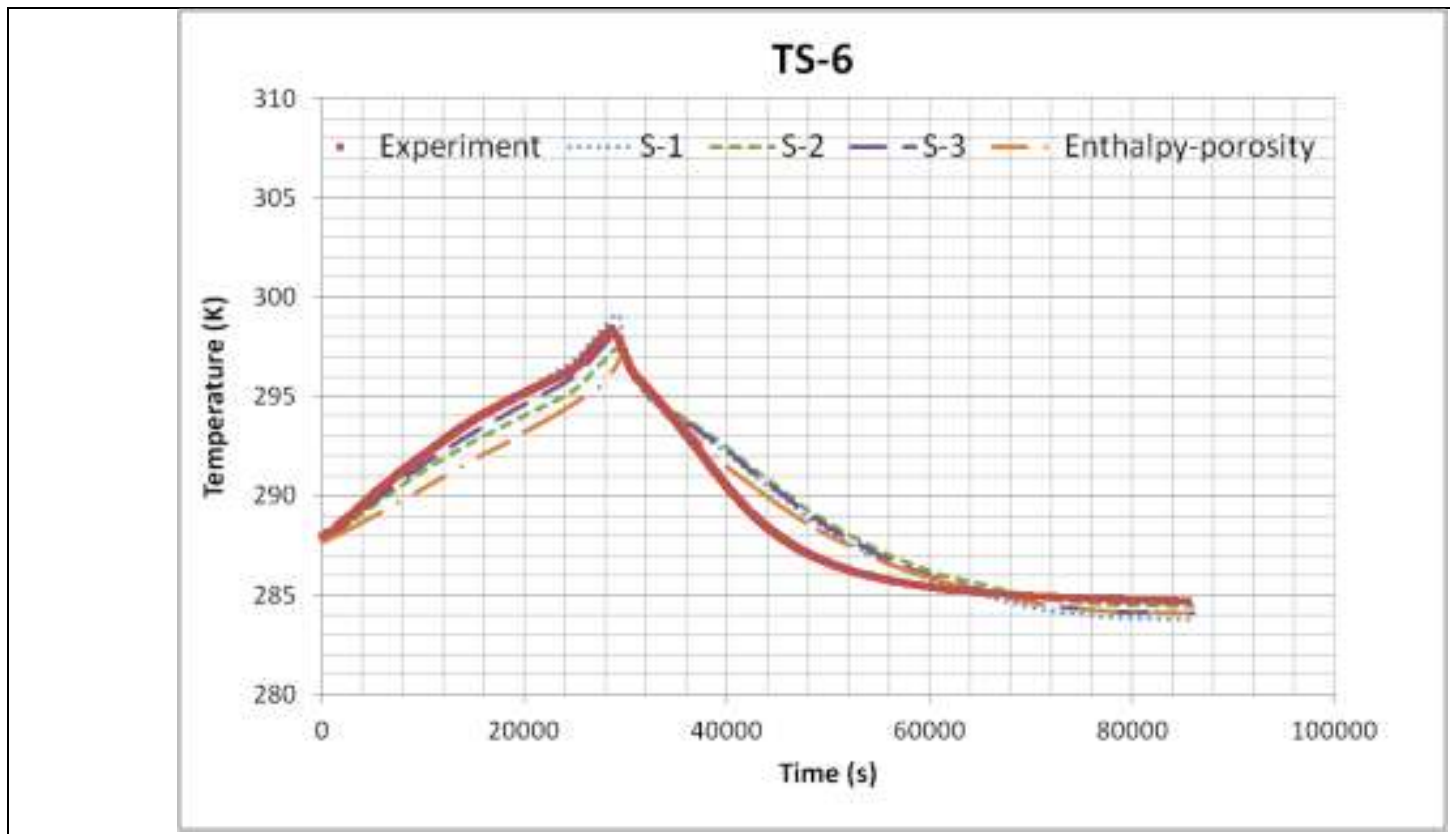

Fig. 9(c). TS-6 Ventilated experimental and simulated temperatures

Fig. 9 shows the general temperature progression in the test cell for the ventilated case. Similar to the non-ventilated case, the different phase change models produce different temperature trends and errors, as shown in Fig. 10. In this case, the denominator for Eq. (9) is the difference between the start and the peak temperatures in the experiment. 


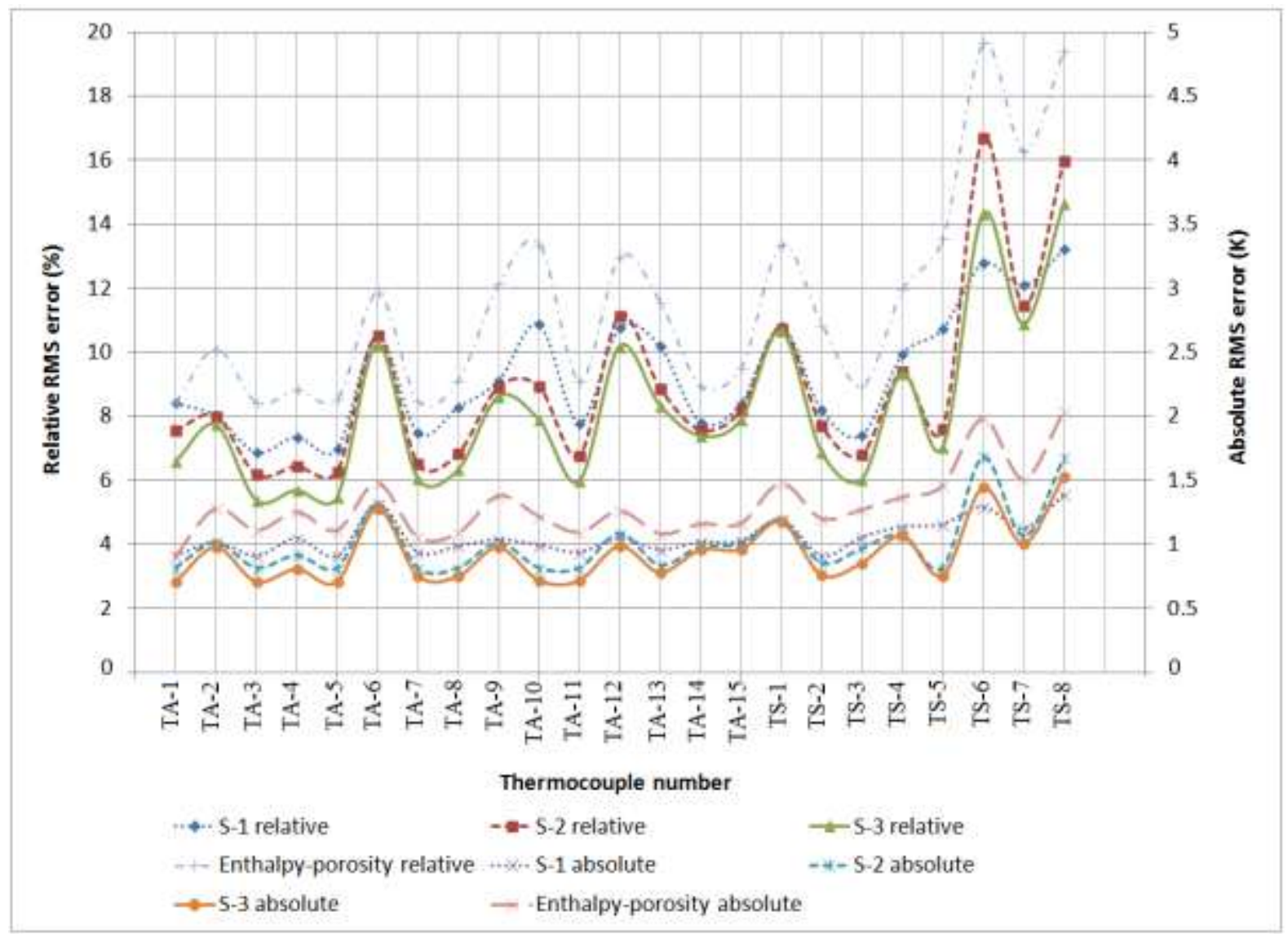

Fig. 10. Local error analysis for ventilated scenario

The absolute error varies between $0.7-1.5 \mathrm{~K}$ and $0.8-2.0 \mathrm{~K}$, corresponding to relative errors of $5.4-13.4 \%$ and $6.0-19.6 \%$ for the air and surface temperatures, respectively. Similarly in this case, the higher surface errors can be attributed to the uneven distribution of PCM in the boards. The overall average errors are found to be $9.25 \%(1.03 \mathrm{~K}), 8.8 \%$ $(0.97 \mathrm{~K})$ and $8.06 \%(0.91 \mathrm{~K})$ for S-1, S-2 and S-3, respectively, while the average error for the enthalpy porosity model is again higher, at $12.5 \%(1.3 \mathrm{~K})$, than the curved-fit models. . As the relative errors are below $20 \%$, using the justification proposed in [16], the validation of the CFD models for the ventilated case can be considered acceptable. 


\subsection{Discussion}

The validation results represent a typical situation in which PCM boards are used for overheating prevention in intermittently occupied buildings, by absorbing excessive heat during the day and releasing it at night. Even without the modelling of radiation (which was assumed negligible in Section 2.1), the models in this study are considered valid based on the relative error being less than $30 \%$.

It is interesting to note that the choice of PCM sample does not as heavily impact the errors when the UDF models are used. However, a mean improvement of $0.5 \mathrm{~K}$ is obtained with the implementation of the S-3 model, compared to the enthalpy-porosity model. Depending on the type of building, where the comfort temperature ranges are different: such as, 7K in airports or $2 \mathrm{~K}$ in offices [26], the importance of appropriately simulating phase change will become higher as the building temperature range becomes smaller. For instance, a difference of $0.5 \mathrm{~K}$ in temperature prediction may represent a significant error in a building where the temperature only varies within $2 \mathrm{~K}$. These errors should therefore be carefully considered when applying CFD to the thermal evaluation of built environments with PCM. In this study, the main errors can be attributed to: the uncertainty in the thermocouples; the uncertainty in the curve-fits for the external air temperature, PCM enthalpy and temperature data; the non-uniformity in PCM distribution; the uncertainty in the ventilation flow rate; and the non-consideration of radiation.

As mentioned previously, passive PCM systems rely on cool night ventilation for charging. The following sub-sections thus describe the effectiveness of CFD to predict the performance of PCM boards for the more popular ventilated case in terms of: the air flow and temperature distribution in the building; the heat transfer rates with different night 
ventilation rates; and the effective use of PCM boards. The results are for S-3, with the lowest errors in the validation study.

\subsection{Temperature distribution with/without PCM-Clay board}

Temperature distribution in the built environment becomes important as the building geometry becomes larger and more complex. In such situations, thermal stratification becomes an important factor in the efficient energy design of the building. In this study, the test cell is closed during the heating period, and thus buoyancy, due to the heater is the dominant force in the air flow, as shown in the temperature contours of Fig. 11 . The experimental study [31] suggests that an aspect ratio (height/width) $<1$ causes stable stratification, as the propensity for turbulent mixing and overturning at the top of the air domain is lower. In this case, the aspect ratio of the test cell with respect to the $z$-direction is 1.08 , while the aspect ratio with respect to the $x$-direction is 1.75 . The qualitative results from Fig. 11 abide by the empirical observations made in [31], as although the aspect ratios of the cell are slightly higher than 1 , they are not high enough to completely destroy stratification. Thus both stratification and a slight overturning near the walls are observed in this simulation.

Fig. 11 also shows the temperature contours and profiles in the test cell at the end of the heating period, comparing a test cell with PCM-Clay board and a test cell with plasterboard. 


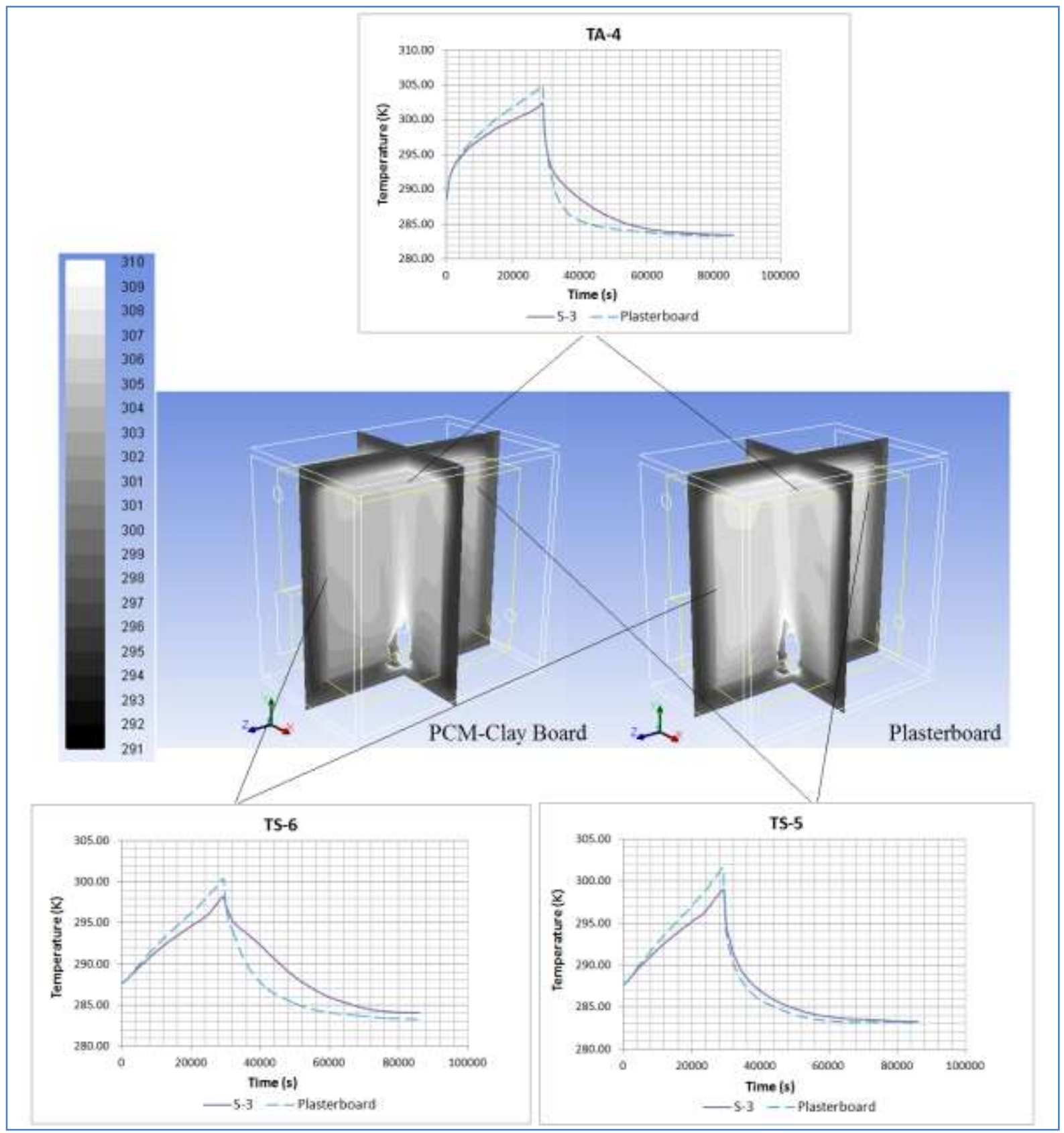

Fig. 11. Comparison of Temperature evolutions at 3 points in the test cell, and Temperature contours $(\mathrm{K})$ at the end of the heating period with PCM-Clay board and Plasterboard on the walls

It can be observed from the contour plots that the airflow is dominated by the buoyancy generated from the heater. A reduction of $3 \mathrm{~K}$ in the peak air temperature and a lower temperature swing are obtained with the addition of the PCM-Clay board, relative to plasterboard, as shown by the temperature evolutions in Fig. 11. Vertical temperature stratification in the air domain of the $\mathrm{PCM}$ cell is $\approx 3 \mathrm{~K} / \mathrm{m}$ compared to $\approx 4 \mathrm{~K} / \mathrm{m}$ in the 
plasterboard cell, and stratification in the PCM cell is more uniform compared to the plasterboard cell. A more uniform and less stratified environment in the occupied zone provides better thermal comfort [32]. The determination of the velocity, temperature and turbulence fields from the CFD results may further improve the evaluation of local thermal comfort [33], which is otherwise not available for zonal models.

\subsection{Heat transfer rates}

While conduction is the dominant heat transfer mechanism within the boards, convection occurs between the boards and the air domain (natural convection during the heating/occupied period and forced convection during the night ventilation period). Fig. 12 shows the area-weighted heat flux on the internal side of the test cell walls, which aims at determining the energy impact of PCM-clay board and plasterboard during the day, and the effects of different ventilation rates (convective heat transfer coefficients) on the PCM boards during night ventilation charging.

The time-averaged convective heat transfer coefficient $\left(h_{c}\right)$ during night ventilation is obtained by Eq. (10) [34] between the start of ventilation, and either the simulation end time or the time where $\bar{q}=0$.

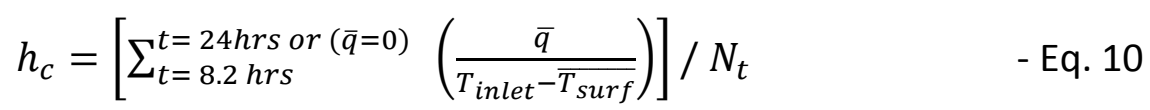




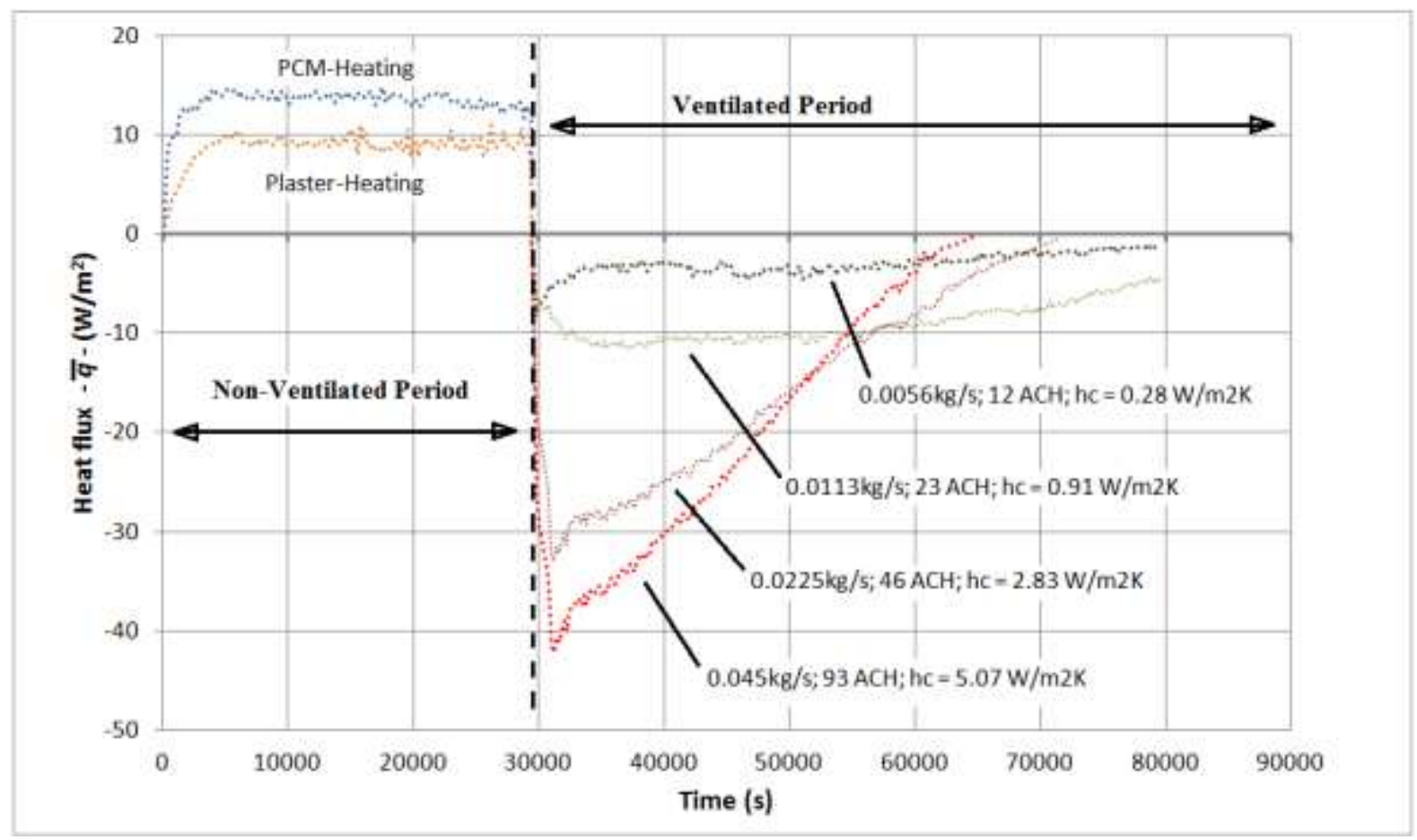

Fig. 12. Area-weighted wall heat flux with PCM and plaster boards, and with different night ventilation rates for PCM boards only

Fig. 12 shows that during the heating phase, the heat flux to the PCM wall is higher than the plasterboard wall, due to the lower wall temperatures of the PCM board during phase change. The average increase in wall heat flux into the walls of $5 \mathrm{~W} / \mathrm{m}^{2}$ with the addition of the PCM-board signifies that the building envelope is providing an extra $5 \mathrm{~W} / \mathrm{m}^{2}$ of cooling, compared to plasterboard. This corresponds to an extra cooling effect of $25 \mathrm{~W}$ for this test cell, compared to plasterboards, with an internal heat gain of $100 \mathrm{~W}$ and without air-conditioning systems.

Fig. 12 also depicts the impact of night ventilation on the PCM boards. The outdoor air, described by the temperature profile in Fig. 3, is introduced into the space through the sidewall inlet at different ventilation rates. As the wall $h_{c}$ increases with increasing ventilation rates, the heat flux out of the walls also increases. This corresponds to a faster re-charge of the PCM boards, improving their efficiency. Fig. 12 shows that with heat transfer coefficients of 5.07, 2.83, 0.91 and $0.28 \mathrm{~W} / \mathrm{m}^{2} \mathrm{~K}$, the PCM boards are fully recharged 
after $9,11,17$ and $23 \mathrm{hrs}$, respectively (Note that the last two charging times have been linearly extrapolated). In this study, as the externally blown air is just below the freezing end temperature of the PCM, $\bar{q}=0$ can be used to justify full-recharge of the boards. In other cases, monitoring the liquid fraction may be more appropriate. The relatively low reduction in charging times as $h_{c}$ increases from 2.83 to $5.07 \mathrm{~W} / \mathrm{m}^{2} \mathrm{~K}$ is explained by the fact that as $h_{c}$ becomes large, the low thermal diffusivity of the PCM board becomes more dominant and limits the heat transfer rates in the boards. In this case, a wall heat transfer coefficient greater than $2.83 \mathrm{~W} / \mathrm{m}^{2} \mathrm{~K}(46 \mathrm{ACH})$ would be adequate, as it would completely recharge the PCM boards before the end of the simulation.

\subsection{Effective use of PCM}

In order to extract the full potential of PCM boards, they have to be suitably placed in the building. The liquid fraction is a useful parameter to quantify their effective use. The liquid fraction used here is obtained using the procedure described in [25] for S-3. 


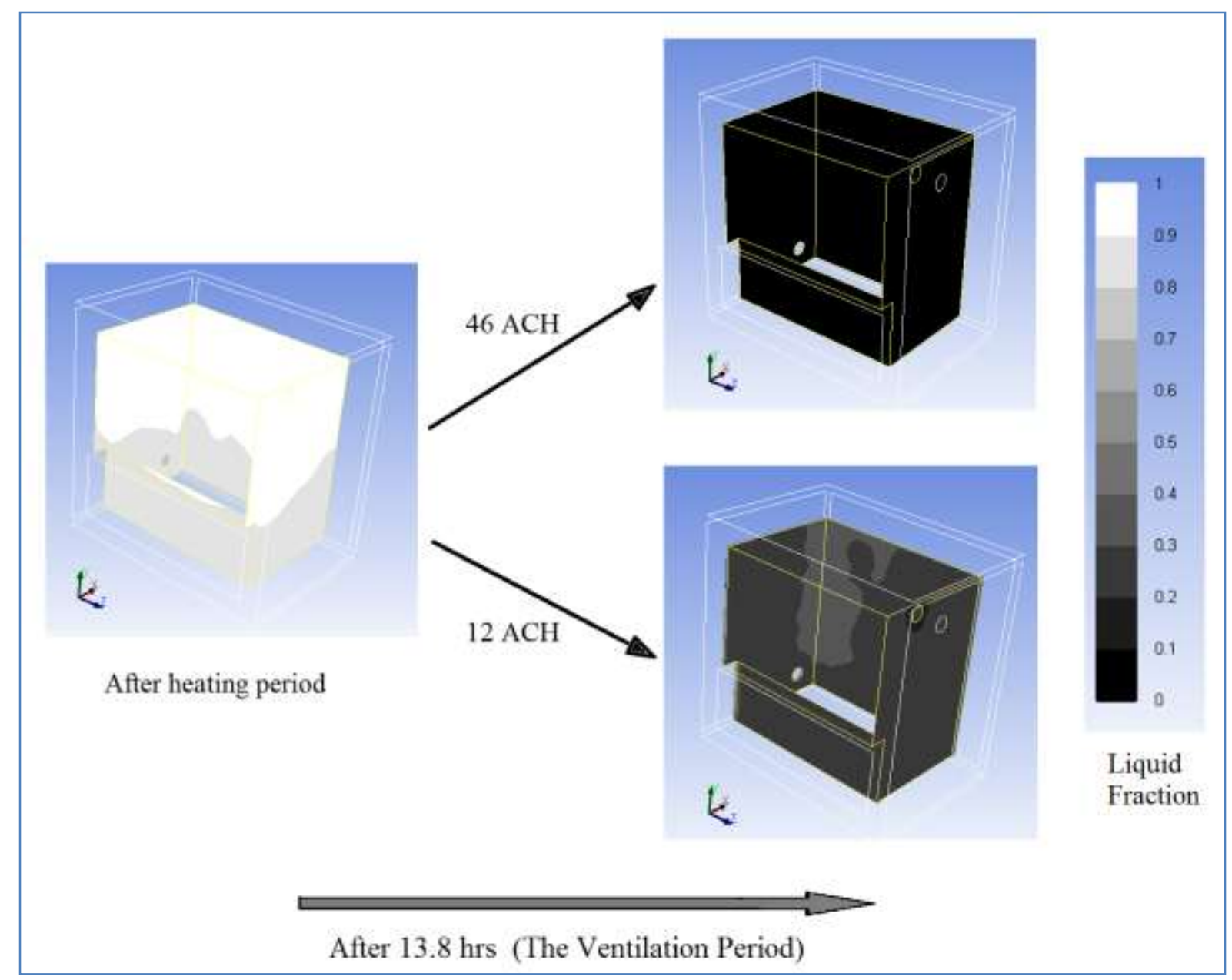

Fig. 13. Liquid fraction change for different ventilation rates

The qualitative observations from Fig. 13 infer that the top part of the test-cell undergoes full phase change after the heating period. The liquid fraction in the lower portion of the cell is $0.8-0.9$, signifying that only $80-90 \%$ of the PCM has been used in the cooling process. This is due to the effect of temperature stratification in the space. In order to optimise the boards' performance, air mixing strategies can be considered for the space or the PCM should be concentrated at the top part of the wall and ceiling of the cell.

Fig. 13 also shows the re-charging effects of different ventilation rates at the end of the simulations. Using $46 \mathrm{ACH}$ completely reduces the overall liquid fraction to 0 , and hence completely recharges the PCM boards. Conversely, using $12 \mathrm{ACH}$ recharges the PCM to 30 $50 \%$ for the same time period. For this latter ventilation rate, the wall temperatures near 
the outlet are affected by the airflow, as shown by an area of higher liquid fraction in Fig.

13.

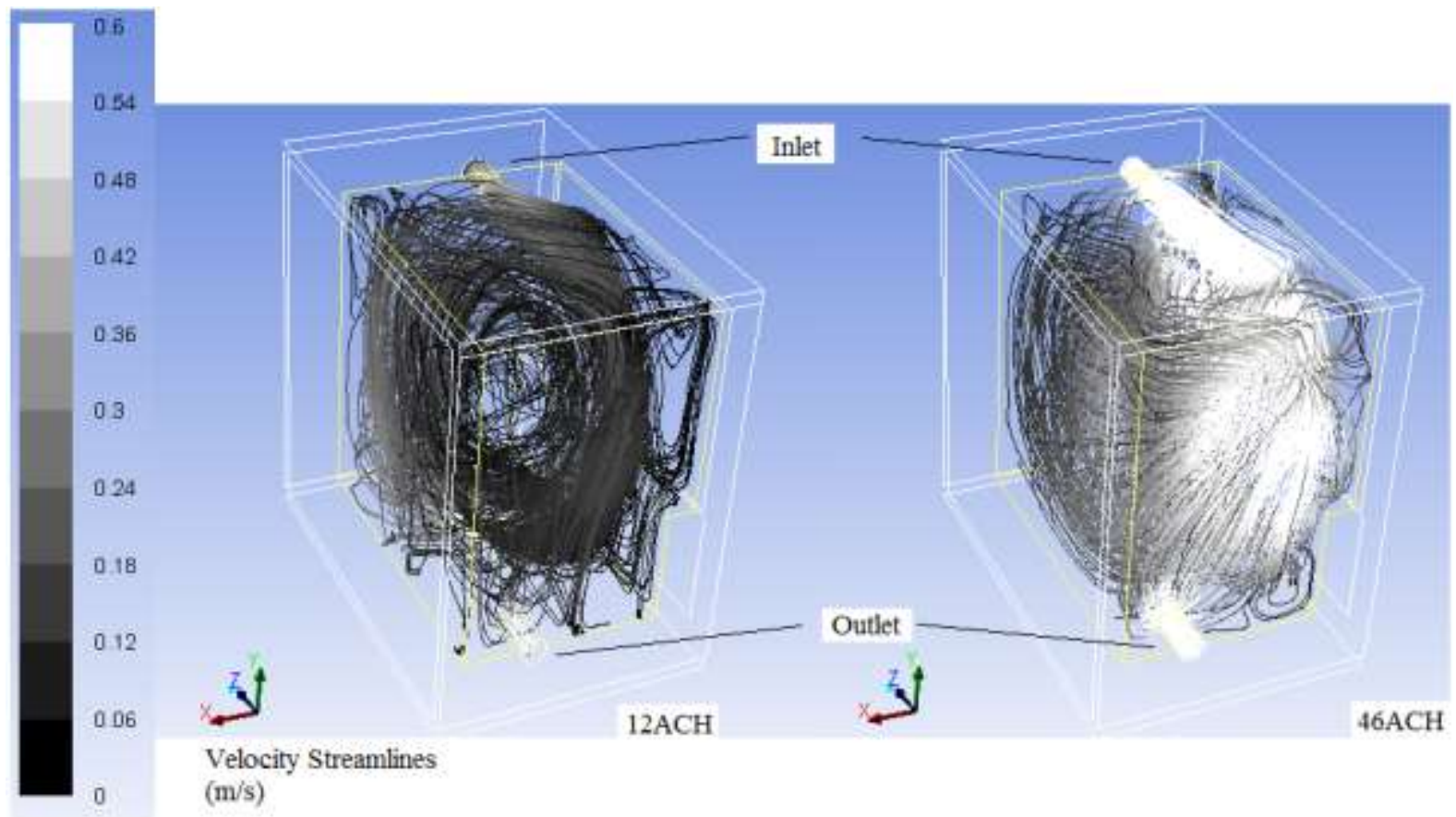

Fig. 14. Velocity streams for ventilation rates of $12 \mathrm{ACH}$ and $46 \mathrm{ACH}$

Fig. 14 suggests that the airflow at this area is low at $12 \mathrm{ACH}$ compared to the mixing propensity of $46 \mathrm{ACH}$, and hence the low heat transfer from the wall. The ventilation rate can therefore be increased or an air inlet with swirl diffusers can be used to generate mixing in the space at $12 \mathrm{ACH}$, and further reduce the liquid fraction. This level of detail cannot be obtained from zonal models.

\subsection{Conclusions}

This study evaluates the effectiveness of: i) PCM clay wall boards to reduce peak indoor temperatures of non-air conditioned spaces in the summer months, and ii) the use of CFD for the modelling of air flows and temperatures in these spaces. The experimental tests 
were carried in a test cell within an environmental test chamber which simulates the variation of external temperatures. The results show that:

- the PCM clay wall boards tested can provide up to $3 \mathrm{~K}$ reduction in the peak temperature of indoor spaces compared to conventional traditional plasterboard and can prevent overheating in the summer months. The performance of the clay boards will of course depend on the quantity of PCM used, the characteristics of the building fabric and the internal and external heat gains.

- the performance of the CFD simulations depends to a certain extent on the approach used for the simulation of the PCM in the board. Including the actual melting and freezing characteristics of the PCM obtained from DSC analysis, improves the simulation accuracy compared to the standard enthalpy-porosity approach employed in commercial CFD codes by about $4 \%(0.5 \mathrm{~K})$.

- the average absolute error in the simulations compared to the experimental results was found to be $1.0 \mathrm{~K}$. These errors are acceptable judged by other studies and uncertainties in the measurements, but can be important in applications where the temperature ranges encountered are small.

- the qualitative results show that the temperature stratification effects can be adequately predicted with the CFD modelling and together with the liquid fraction term, can enable more efficient building design using PCM boards for both natural and forced convection scenarios. In free-floating buildings, the impact of PCM boards during day-time can be evaluated and appropriate ventilation rates and configurations can be investigated to ensure complete charging of the PCM. 
- Due to the extensive simulation times required, CFD can mainly be used as a design tool to determine areas of concern and to investigate improvements in the design with PCM boards over a short period of time. A number of discrete time dependent simulations, however, can be used with different weather data to gain an understanding of the influence of the variation in external conditions on the thermal response of indoor spaces equipped with PCM boards.

\subsection{Acknowledgements}

This work was made possible through sponsorship from the UK Engineering and Physical Sciences Research Council (EPSRC), Grant No: EP/H004181/1. The Authors also acknowledge the help of Mr. C. Xanthos and Mrs. E. Pike-Wilson in the construction of the HVAC rig and the experimental test cell, respectively, and Ebb Co. Ltd. for providing the PCM-Clay boards for testing. 


\subsection{References}

[1] Zhang Y, Zhou G, Lin K, Zhang Q, Di H. Application of latent heat thermal energy storage in buildings: State-of-the-art and outlook, Building and Environment, 42(2007), pp. 2197-2209.

[2] Zalba B, Marin JM, Cabeza LF, Mehling H. Free-cooling of buildings with phase change materials, International Journal of Refrigeration, 27(2004), pp. 839-849

[3] Zhou D, Zhao CY, Tian Y. Review on thermal energy storage with phase change materials (PCMs) in building applications, Applied energy 92(2012), pp. 593-605

[4] Arce P, Castellon C, Castell A, Cabeza LF. Use of microencapsulated PCM in buildings and the effect of adding awnings, Energy and Buildings 44(2012), pp. 88-93

[5] Susman G, Dehouche Z, Cheechern T, Craig S. Tests of prototype PCM 'sails' for office cooling, Applied Thermal Engineering 31(2011), pp. 717-726

[6] Shilei L, Guohui F, Neng Z, Li D. Experimental study and evaluation of latent heat storage in phase change materials wallboards, Energy and Buildings 39(2007), pp. 1088-1091

7] International Energy Agency IEA, Energy Conservation through Energy Storage Programme, Annual Report 2010, pp. 15

[8] Nagano K, Takeda S, Mochida T, Shimakura K, Nakamura T. Study of a floor supply air conditioning system using granular phase change material to augment building mass thermal storage - Heat response in small scale experiments, Energy and Buildings, 38(2006), pp. 436-446

[9] Medved S, Arkar C. Correlation between the local climate and the free-cooling potential of latent heat storage, Energy and Buildings, 40(2008), pp. 429-437

[10] Heim D, Clarke J. Numerical modelling and thermal simulation of phase change materials within ESP-r, Eighth International IBPSA Conference, Eindhoven, Netherlands, August 11-14, 2003

[11] Bony J, Citherlet S. Numerical model and experimental validation of heat storage with phase change materials, Energy and Buildings 39 (2007), pp. 1065-1072

[12] Chen Q. Ventilation performance prediction for buildings: A method overview and recent applications, Building and Environment 44(2009), pp. 848-585

[13] Rundle CA, Lightstone MF, Oosthuizen P, Karava P, Mouriki E. Validation of computational fluid dynamics simulations for atria geometries, Building and Environment 46(2011), pp. 1343-1353

[14] Hussain S, Oosthuizen PH. Numerical investigations of buoyancy-driven natural ventilation in a simple atrium building and its effect on the thermal comfort conditions, Applied Thermal Engineering, 40(2012), pp. 358-372

[15] Hussain S, Oosthuizen PH, Kalendar A. Evaluation of various turbulence models for the prediction of the airflow and temperature distributions in atria, Energy and Buildings 48(2012), pp. $18-28$ 
[16] Zhang Z, Zhang W, Zhai Z, Chen Q. Evaluation of various turbulence models in predicting airflow and turbulence in enclosed environments by CFD: Part-2 - comparison with experimental data from literature, HVAC\&R Research 13(2007), pp. 871-886.

[17] Gebremedhin KG, Wu BX. Characterization of flow field in a ventilated space and simulation of heat exchange between cows and their environment, Journal of Thermal Biology, 28 (2003), pp. 301-319.

[18] Rohdin P, Moshfegh B. Numerical predictions of indoor climate in large industrial premises. A comparison between different $k-\varepsilon$ models supported by field measurements, Building and Environment 42(2007), pp. 3872-3882

[19] Zhai Z, Zhang Z, Zhang W, Chen Q. Evaluation of various turbulence models in predicting air airflow and turbulence in enclosed environments by CFD. Part-1: Summary of prevent turbulence models, HVAC and R Research 13 (2007), pp. 853-870

[20] Tanasic N, Jankes G, Skistad H. CFD analysis and airflow measurements to approach large industrial halls energy efficiency: A case study of a cardboard mill hall, Energy and Buildings 43(2011), pp. 1200-1206

[21] Suarez MJ, Gutierrez AJ, Pistono J, Blanco E. CFD analysis of heat collection in a glazed gallery, Energy and Buildings 43(2011), pp. 108-116

[22] ANSYS FLUENT User's Guide, Release 13.0, Nov 2010: pp. 699

[23] Mehling H, Cabeza LF, Heat and cold storage with PCM. 1st Ed. Springer-Verlag Heidelberg; 2008

[24] Ye WB, Zhu DS, Wang N. Numerical simulation on phase-change thermal storage/ release in a plate-fin unit, Applied Thermal Engineering 31 (2011), pp. 3871-3884

[25] Gowreesunker BL, Tassou SA, Kolokotroni M. Improved simulation of phase change processes in applications where conduction is the dominant heat transfer mode, Energy and Buildings 47 (2012), pp. 353-359

[26] Chartered Institute of Building Services Engineering Guide A (2006)

[27] Technical specifications for the DSC 4000/6000 Differential Scanning Calorimeters, Perkin Elmer Inc, 2009

[28] Feldman D, Banu D. DSC analysis for the evaluation of an energy storing wallboard, Thermochimica Acta, 272(1996), pp. 243-251

[29] Veluri SP, Roy CJ, Luke EA. Comprehensive Code Verification Techniques for Finite Volume CFD Codes, Computers \& Fluids (2012), doi: http://dx.doi.org/10.1016/j.compfluid.2012.04.028

[30] Alauzet F, Frey PJ, George PL, Mohammadi B. 3D transient fixed point mesh adaptation for timedependent problems: Application to CFD simulations, Journal of Computational Physics 222(2007), pp. 592-623 
[31] Hunt GR, Cooper P, Linden PF. Thermal stratification produced by plumes and jets in enclosed spaces, Building and Environment, 36(2001), pp. 871-882

[32] Chao CYH, Wan MP. Airflow and air temperature distribution in the occupied region of an underfloor ventilation system, Building and Environment 39(2004), pp. 749-762

[33] ANSI/ASHRAE Standard 55-2004: Thermal Environmental Conditions for Human occupancy (2004), pp. 8

[34] Fisher DE, Pederson CO. Convective heat transfer in building energy and thermal load calculations, ASHRAE Transactions, Part 2, 103 (1997), pp. 137-148 